\title{
HUMAN OCCUPATION AND PALEOENVIRONMENTS IN SOUTH AMERICA: EXPANDING THE NOTION OF AN “ARCHAIC GAP”
}

\author{
Astolfo G. de M. Araujo* \\ Luís B. Pilo** \\ Walter A. Neves** \\ João Paulo V. Atui**
}

\begin{abstract}
ARAUJO, A.GM.; PILÓ, L.B.; NEVES, W.A.;ATUI, J.P.V. Human occupation and paleoenvironments in South America: expanding the notion of an "Archaic Gap”. Rev. do Museu de Arqueologia e Etnologia, São Paulo, 15-16: 3-35, 2005-2006.
\end{abstract}

RESUMO: Uma revisão das informações arqueológicas produzidas no Brasil e países vizinhos durante as últimas décadas, aliada a uma análise de estudos paleoambientais recentes, sugerem que durante o Holoceno Médio amplas áreas da América do Sul deixaram de ser ocupadas por grupos humanos. Dados independentes, como datações de esqueletos humanos, estratigrafia de abrigos rochosos e cronologia de sítios arqueológicos a céu aberto convergem para a idéia de que tais áreas foram, no mínimo, fortemente depopuladas. Dados paleoambientais sugerem que eventos de seca constituíram a principal causa por trás das tendências observadas. Nossas conclusões expandem a noção já existente de que estresses climáticos têm um papel importante na conformação de assentamentos humanos em ambientes marginais, como desertos e altitudes elevadas, mostrando que o mesmo pode ocorrer nas terras baixas tropicais e subtropicais.

UNITERMOS: Arqueologia - Paleoambiente-Holoceno-Brasil - Argentina.

\section{Introduction}

The occurrence of dry climatic periods during the Early and Mid-Holocene in South America,

(*) Departamento do Patrimônio Histórico - Secretaria Municipal da Cultura, Prefeitura do Município de São Paulo astwolfo1@yahoo.com.br

$\left({ }^{* *}\right)$ Laboratório de Estudos Evolutivos Humanos, Instituto de Biociências da Universidade de São Paulo.

Luís B. Pilo lbpilo@yahoo.com.br;

Walter A. Neves waneves@ib.usp.br;

João Paulo V.Atui jpvatui@hotmail.com related respectively to the Younger Dryas and to changes in Earth's precession, is a phenomenon recognized by several authors (e.g., Absy et al. 1991; Baker et al. 2001; Grimm et al. 2001; Grosjean et al. 2001; Ledru et al. 1996; Ledru et al. 2002; Melo et al. 2001; Sifeddine et al. 2003). The consequences of these events for the human occupation, at least in the Andean region, has been recently acknowledged (Grosjean et al. 1997; Nuñez et al. 2001), with a solid corpus of data showing abandonment of entire areas by humans due to dry conditions. However, the analyses done so far tend to restrict the influence that such climatic 
ARAUJO, A.G.M.; PILÓ, L.B.; NEVES, W.A.; ATUI, J.P.V. Human occupation and paleoenvironments in South America: expanding the notion of an “Archaic Gap”. Rev. do Museu de Arqueologia e Etnologia, São Paulo, 15-16: 3-35, 2005-2006.

variables would have in humans, focussing on marginal environments such as deserts or high altitude settings. In this paper we try to put the problem of human migrations and regional abandonment in South America into a broader perspective, by compiling archaeological data coming from Brazil and northeastern Argentina (both low altitude settings), and by discussing palaeoenvironmental evidence gathered outside the Andes. We deal with two sources of archaeological information, both coupled with paleoenvironmental background. On the one hand, we present new data coming from our research in Lagoa Santa region, Central Brazil, the main focus of which is the Paleoindian occupation. On the other hand, we analyze under this perspective data published by Brazilian and other South American researchers in the last decades. The ideas put forth here represent a much extend and updated version of a paper dealing with human abandonment of vast areas in Brazil during the mid-Holocene (Araujo et al. 2005).

\section{Paleoenvironmental background}

The interpretation of climatic conditions during the late Pleistocene and Holocene in Brazil suffers from a relative paucity of data, when contrasted to the vast territory that is under scrutiny. Even so, it is already possible to perceive some trends that may be useful for understanding the patterns observed in the archaeological record.

The main climatic agents responsible for the distribution of rains in Brazil are the South Atlantic Anticyclone, the Inter-Tropical Convergence Zone (ITCZ) and the Antartic polar fronts (Garreaud 2000; Marengo and Rogers 2001; Nimer 1989). While the southern and southeastern portions of the country are more affected today by the South Atlantic Anticyclone and Antartic polar fronts, the climate in northern and northeastern regions is strongly subject to the annual shifts of the ITCZ, a low-pressure belt characterized by abundant precipitation and turbulence.

Climate changes during the late Pleistocene and Holocene in South America are generally attributed to changes in the positioning of the ITCZ (Behling 2002; Behling and Hooghiemstra 2001; De Oliveira et al. 1999; Fritz et al. 2001; Grimm et al. 2001; Iriondo 1999; Ledru and Mourguiart 2001; Marengo and Rogers 2001; Servant et al. 1993;
Sifeddine et al. 2003); but see a different view in Betancourt et al. (2000). Others argue for the relevance of the weakening or the complete disappearence of the ITCZ (Bradbury et al. 2001; Markgraf et al. 2000). Other factors such as the El Niño/Southern Oscillation (ENSO) are being recently regarded as of minor importance during the first half of the Holocene (Enfield and MestasNuñez 2001; Haberle and Ledru 2001; Jenny et al. 2002; Martin et al. 1993; Moy et al. 2002), its activity increasing only after 5000 RCYBP.

During the austral summer, the ITCZ shifts southward due to the warming of the continent. The main argument for the role of the ITCZ in late Pleistocene and Holocene climatic changes is that variations in the Earth's orbital parameters promoted conditions of reduced seasonality between 10,500 and 7500 RCYBP (Martin et al. 1997), causing a weakening (or disappearance) of the ITCZ, and therefore a lesser southward displacement. The weakening of the ITCZ would allow Antartic polar fronts to penetrate farther northward, causing cooling and increasing moisture in some settings (De Oliveira et al. 1999; Ledru 1993). At the same time, reduced seasonality would implicate in the lack of contrasting climatic conditions that lead to ENSO events (Enfield and Mestas-Nuñez 2001:27).

\subsection{Dry Periods During the Holocene in Brazil}

Recent paleoenvironmental data coming from Brazil are finally shedding some light on the question of the climatic trends that occurred during the Holocene. Of course, these trends show considerable differences depending upon the area investigated. Sites discussed in this section are shown in Figure 1.

\subsubsection{Central / Southeastern Brazil}

For central Brazil some authors believe, based on pollen records, that a very dry Last Glacial Maximum and Late Glacial (since 19,000 RCYBP) was followed by an increase in moisture beginning ca. 6000 - 5000 RCYBP, leading to modern conditions (Barberi et al. 2000; Ferraz-Vicentini and Salgado-Laboriau 1996; Salgado-Laboriau et al. 1997; Salgado-Labouriau et al. 1998). In the same region, however, other researchers found evidence of a somewhat different scenario, with a drier and cooler Last Glacial Maximum (LGM) 


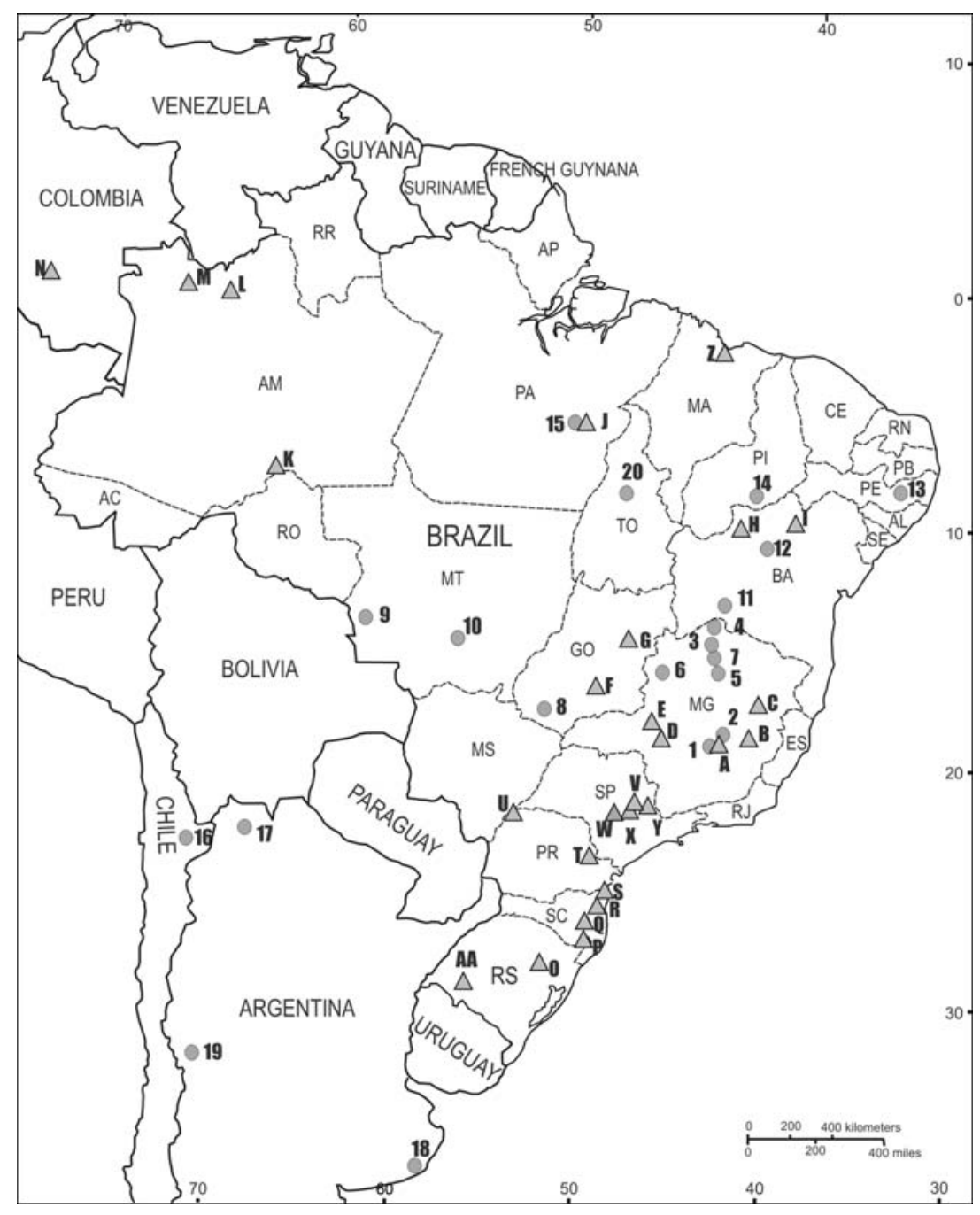

Figure 1. Archaeological sites (circles) and paleoenvironmental studies (triangles) cited in the text.

1 = Lagoa Santa; 2 = Santana do Riacho; 3 = Lapa do Boquete and Lapa dos Bichos; 4 = Lapa do Dragão; 5 = Lapa Pequena; 6 = Gruta do Gentio II; 7 = Lapa do Varal; 8 = GO-JA-01; 9 = MT-GU-01; 10 = Santa Elina; $11=$ BA-RC-28; 12 = Abrigo do Pilão; 13 = Furna do Estrago; 14 = Pedra Furada (São Raimundo Nonato area); 15 = Gruta do Gavião; 16 = Atacama; 17 = Inca Cueva 4; 18 = Cueva Tixi, Cerro El Sombrero, Cerro La China; 19 = Agua de La Cueva; 20 = Lajeado.

$A=$ Lagoa dos Olhos, Lagoa Santa; $B$ = Lago Silvana and Dom Helvécio; $C=$ Lago do Pires and Água Preta de Baixo; $D$ = Salitre; $E$ = Serra Negra; F = Cromínia; $G$ = Águas Emendadas, Lagoa Bonita, and Lagoa Feia; $H=$ Icatu Dunes; $I=$ Toca da Boa Vista; $J$ = Carajás; $K=$ Humaitá; $L=$ Rio Negro Dunes; $M=$ Lake Pata; $N$ = Pantano de Monica; $O=$ Fazenda do Pinto; $P$ = Serra Rio do Rastro; $Q=$ Morro da Igreja; $R$ = Serra Boa Vista; $S$ = Volta Velha; $T$ = Serra Campos Gerais; $U$ = Paraná River; $V$ = Rio Claro; $W=$ Botucatu; $X=$ Anhembi; $Y=$ Jaguariúna; $Z=$ Caçó Lake; $A$ A = Sao Francisco de Assis. 
ARAUJO, A.G.M.; PILÓ, L.B.; NEVES, W.A.; ATUI, J.P.V. Human occupation and paleoenvironments in South America: expanding the notion of an “Archaic Gap”. Rev. do Museu de Arqueologia e Etnologia, São Paulo, 15-16: 3-35, 2005-2006.

period followed by a cool and moist Late Glacial between ca.10,000 and 8500 RCYBP, followed again by an arid period between ca. 8500 and 4000 RCYBP, and a trend towards modern conditions since then (Behling 2002; Ledru 1993; Ledru et al. 1996; Martin et al. 1997; Servant et al. 1993).

These differences in interpretation can potentially be explained by many factors: problems in comparability of pollen data due to different research methods, problems of chronology related to the interpolation of C14 dates or to radiocarbon reservoir effect Ferraz-Vicentini and SalgadoLaboriau 1996; Geyh et al. 1999; Ledru and Mourguiart 2001; Salgado-Labouriau 1997; Sylvestre et al. 1999), or even to variations in localized, differential moisture gradients due to microclimatic/orographic factors (Behling and Hooghiemstra 2001; Nimer 1989). Recent research tends to differentiate this part of Brazil into two climatic zones: the "core" savanna area would show the trend of increasing moisture during the Holocene, whereas the "peripheral" area, towards the east and the south, would show more oscillations in moisture, probably due to incursions of Antartic polar fronts (Barberi 2001:145) and periods of aridity in the Late Holocene due to increasing ENSO activity or to a northward shift of the ITCZ (De Oliveira et al. 1999:335). This view seems more in accordance with the climatic complexity that probably existed in this vast area during the Holocene, and which can be appreciated in the recent compilation carried out by (Ledru et al. 1998). However, the issue is far from being settled. Most of the palynological records from central Brazil supporting the "increasing Holocenic moisture” model suffer from insufficient chronological control: for example, at Águas Emendadas, the late Pleistocene/early Holocene is somewhere between dates of 21,450 \pm 100 RCYBP and $7220 \pm 50$ RCYBP (Barberi et al. 2000); at Cromínia, the interpolation is between 13,150 \pm 50 RCYBP and $6680 \pm 90$ RCYBP (Salgado-Labouriau et al. 1998); at Lagoa dos Olhos the same occurs between 15,630 \pm 110 and $6790 \pm 140$ RCYBP, and at Lagoa da Serra Negra between 14,340 \pm 90 and $5000 \pm 80$ RCYBP (De Oliveira 1992); at Lagoa Bonita, there is an interval between 22,980 \pm 60 RCYBP and $6300 \pm 40$ RCYBP (Barberi 2001). On the other hand, the three palynological studies supporting the hypothesis of a peak in moisture around 8000 RCYBP followed by dryness in the mid-Holocene and a return of moisture in the late Holocene show the best chronological controls: Salitre has 14 radiocarbon dates ranging between 32,000 RCYBP and 3080 RCYBP with no major intervals between them (Ledru 1993), and further studies using different paleoenvironmental markers (charcoal concentration, carbon isotopes, and phytoliths) supported Ledru's interpretations (Alexandre et al. 1999; Vernet et al. 1994); good chronological control is also present at Lago do Pires, with six dates ranging from 9500 RCYBP to 970 RCYBP (Behling 1998). The third study site, at Lake Silvana (Rodrigues-Filho et al. 2002), $180 \mathrm{~km}$ south from Lago do Pires, also shows a very dry episode with minor climatic oscillations between 10,000 RCYBP and 8500 RCYBP, followed by an expansion of forest around 8500 RCYBP. Since there are no dates between 8000 RCYBP and the top of the column, it is not possible to know if a second dry period occurred in the mid-Holocene.

An independent paleoclimatic study, dealing with sedimentologic analysis and accumulation of organic carbon at lakes in central and southeastern Brazil (Lagoa Feia Lake, Água Preta de Baixo Lake, and Dom Helvecio Lake) also seem to corroborate the mid-Holocene dryness pattern (Turcq et al. 2002). The authors' main conclusion is that the sedimentary accumulations of carbon in the lakes studied are probably linked to changes in the lake level and regional climates. The drier climate in the early to mid-Holocene generally corresponds to lower carbon accumulation rates, while the more humid late Holocene is characterized by high carbon accumulation.

Another independent study undertaken at Tamanduá river in northern São Paulo State (Turcq et al. 1997) also seems to corroborate the interpretations for Salitre and Lago do Pires. Adry interval between 17,000 RCYBP and 10,000 RCYBP was followed by wet periods after 10,000 RCYBP and before 6000 RCYBP. A drier period after 6000 RCYBP caused reduction of discharge, while maintaining a high water table.

Paleoclimatic research using carbon isotopes in charcoal and soil (Gouveia et al. 2002) support an interpretation of a dry mid-Holocene followed by an increase in moisture during the late Holocene for three localities (Botucatu, Anhembi, and Jaguariúna) in São Paulo State. The greatest frequency of fires, attributed by the authors to a dry climatic event, occurred between 6000 RCYBP and 3000 
RCYBP. Melo et al. (2001) recorded a similar pattern when studying charcoal particles found in soils near Rio Claro, central São Paulo. Charcoal dates clustered between 8000 RCYBP and 5500 RCYBP, suggesting a drier period.

Further inland, along the Paraná river, paleoenvironmental data seem to indicate somewhat different climatic conditions for late Pleistocene/ Holocene (Stevaux 2000). After a dry LGM and late Glacial, climate became moister between ca. 8000 RCYBP and 3500 RCYBP. A second drier episode occurred between 3500 RCYBP and 1500 RCYBP, followed by a wetter episode leading to the present climate. The author sees a good correlation between these interpretations and paleoclimatic data from NE Argentina, but the same can't be said in relation to the studies carried towards the east (Morro de Itapeva, Santa Catarina, Serra Negra, Salitre). This discrepancy is attributed to topographic differences (Stevaux 2000:82), and probably has also to do with the path of Antartic polar fronts.

\subsubsection{Northeastern Brazil}

There are still few paleoclimatic studies for northeastern Brazil (Behling et al. 2000, Ledru et al. 2002), and the available information does not allow regional generalizations. Auler and Smart (2001) point to the importance of regional differences in climate that can be superimposed over general atmospheric circulation patterns. Nimer (1989) observes that today the rain patterns in NE Brazil are extremely conditioned by orography. The distribution of the dry season is very variable, with mountains being responsible for the abbreviation of the dry season, and flats responsible for its extension.

At Toca da Boa Vista, northern Bahia, Auler and Smart (2001) found a period of travertine deposition between 21,000 RCYBP and 9000 RCYBP, suggesting a moister climate. At Icatu river, also in northern Bahia, six radiocarbon dates ranging from 11,000 RCYBP to 4000 RCYBP are coupled with $43 \mathrm{TL}$ dates, bracketing periods of increased aridity (De Oliveira et al. 1999). The period between 11,000 RCYBP and 8900 RCYBP was marked by very moist conditions, followed by a decrease in forest taxa and an increase of savanna. The period between 6800 RCYBP and 6200 RCYBP was possibly semi-arid, followed by moister climatic conditions between 6200 RCYBP and 4500 RCYBP. Between 4500 RCYBP and the present another decline in moisture happened, leading to the extant semi-arid conditions. It is worth noting that this pattern is very close to the observed at Salitre and Lago do Pires, further south.

At southeastern Piauí State, in the São Raimundo Nonato area, pollen found in human coprolites suggests a moister and cooler climate between 8700 RCYBP and 7000 RCYBP (Chaves 2000).

At Caçó Lake, Maranhão State, palynological data coupled with mineralogical analyses (Sifeddine et al. 2003) showed an increase in moisture and temperature from ca. 13,000 RCYBP to 10,500 RCYBP, an event the authors correlate to the onset of sedimentation in the records from Carajás, Salitre, and Icatu. This period was followed by an abrupt oscillation between 10,500 RCYBP and 9000 RCYBP, with a drop in the lake level during a millennia and a subsequent rise in the level during the following 500 years. During the mid-Holocene there is a gradual increase in the lake level until ca. 6000 RCYBP, with minor fluctuations in arboreal pollen percentages up to the present.

\subsubsection{Northern Brazil}

Paleoenvironmental data is extremely scattered across this vast region. At Carajás, in the eastern Amazon basin, there is a rise in lake level ca. 12,500 RCYBP, in the Late Glacial, with an increase in forest taxa. After this, there is a marked mid-Holocene dry period with a peak of dryness around 6000 RCYBP (Absy et al. 1991). In the Late Holocene, after 3000 RCYBP, the forest expanded again reaching its present aspect. This pattern, at least until the Mid-Holocene, is similar to that the already observed at Icatu, Salitre and Lago do Pires, further south.

Dating of eolian dunes in the Rio Negro Basin, northwestern Amazon, showed four peaks of main eolian activity (Carneiro Filho et al. 2002), the last two occurring in the Late Glacial $(17,200$ RCYBP $-12,700$ RCYBP) and in the early Holocene (10,400 RCYBP - 7800 RCYBP). The authors suggest that these periods probably signal an increase in aridity and retreat of vegetation. However, a palynological study carried out at Lake Pata, not very far from the dunes region, showed no 
sign of markedly dry events (Colinvaux et al. 1996), but of cooling, as suggested by the presence of Podocarpus.

In southwestern Amazon, at Campos de Humaitá, a study of carbon isotopes in soil organic matter (Freitas et al. 2001) suggests a changing distribution of $\mathrm{C} 3$ and $\mathrm{C} 4$ plants in response to climate changes. From ca. 17,000 RCYBP to 9000 RCYBP, forests covered the area. This probably wet and cool period was followed by a savanna expansion between 9000 RCYBP and 3000 RCYBP, suggesting a hotter and drier period. From 3000 RCYBP up to present times, forests expanded again due to the extant wet climate.

In the upper Amazon Basin, at Caquetá River in Colombia, palynological studies (Behling et al. 1999; Urrego 1997) tended to indicate a wet period between ca. 10,000 RCYBP and 9000 RCYBP, followed by a drier period until 6500 RCYBP or 4500 RCYBP, depending on the site. Present humid conditions were reached after this dry period.

\subsubsection{Southern Brazil}

Several palynological studies were carried out in recent years for the southern states, and the picture seems to point towards and increasing climatic amelioration throughout the Holocene. Palynological records at Paraná (Serra de Campos Gerais - Behling 1997; Volta Velha - Behling and Negrelle 2001), Santa Catarina (Serra do Rio do Rastro, Morro da Igreja, and Serra da Boa Vista Behling 1995), and Rio Grande do Sul (São Francisco de Paula, Cambará do Sul and São Francisco de Assis - Behling et al. 2001; Behling et al. 2004; Behling et al. 2005) suggest that the Last Glacial Maximum (LGM) and Late Glacial were very dry and cold, with expansion of grasslands where today a variety of forest ecosystems occur (Behling 2002). The Late Glacial, however, was probably somewhat warmer than the LGM. During the Holocene, changes toward wetter conditions started around 6000 RCYBP in southeastern Brazil, and even later in southern Brazil, around 3000 RCYBP (Behling 2002). The coastal area was moister, probably due to orographic factors, as is the case in Volta Velha (Behling and Negrelle 2001), where an incipient rain forest started to develop around 12,300 RCYBP. In the southern highlands, early and mid-Holocene climate was probably marked by a long dry season, preventing the expansion of Araucaria forests. Only in the late Holocene, after about 1500 1000 RCYBP, the annual dry season became shorter, as suggested by Araucaria expansion (Behling 1997, Behling 2002, Behling et al. 2001). Climate in southern/southeastern Brazil is strongly affected by the Antartic polar fronts (Garreaud 2000), and the increased moisture could be related to shifts in this system.

\section{Humans enter the scenario: the "Archaic Gap” at Lagoa Santa}

The Lagoa Santa region, a karstic area encompassing several counties near the city of Belo Horizonte, State of Minas Gerais (Figure 1), is perhaps one of the most widely known archaeological settings of Brazil, and a key area for understanding the peopling of the Americas. Thanks to the Danish naturalist Peter W. Lund, who visited several hundred and excavated many dozens of rockshelters and caves during the mid-nineteenth century, Lagoa Santa became internationally known as the first place in the Americas where the co-occurrence of humans and extinct animals deserve serious investigation (Walter 1948:21, Walter 1958:106). After Lund's death in 1880, interest in the region decreased somewhat, with excavations being resumed only in the beginning of the twentieth century, mostly by other naturalists and amateurs.

After so many decades of research in the area, it is striking that dates for the majority of burials in the Lagoa Santa region cluster around two peaks: between 10,000 and 8000 RCYBP, and between 2000 and 1000 RCYBP (Figure 2). There is, accordingly, a period of 6000 years where human burials were practically absent in sheltered areas. We called this the “Archaic Gap” (Araujo et al. 2003; Araujo et al. 2005). We have raised several hypothesis to explain this "gap": it could be a function of unfavorable climatic conditions that pushed the local human population out of the area; an interruption in local populations' use of the rockshelters for mortuary practices; or a generalized erosive event that washed away the sediments deposited between 8000 and 2000 BP. Favoring the first hypothesis, we generated some evidence suggesting the advent of drier climactic conditions coincident with the "gap". A core sample performed at the bottom of the temporary doline lake near the 
Cerca Grande outcrop revealed two discrete dark organic levels, the upper one at $50 \mathrm{~cm}$ depth, the lower at $210 \mathrm{~cm}$. We interpreted these levels as the result of two discrete periods of permanent water in the lake, hence two periods of higher humidity. The age obtained for the upper organic level was 2800 \pm 40 RCYBP, and for the lower level $9680 \pm 230$ RCYBP.

A late discrete episode of high humidity in the Lagoa Santa region was also confirmed by a core sample performed by us in the temporary doline lake near the Sumidouro outcrop. Two organic levels, found at $115 \mathrm{~cm}$ and $275 \mathrm{~cm}$ depth, were dated to $1570 \pm 70$ RCYBP and $2630 \pm 40$ RCYBP respectively. The underground water table near Sumidouro prevented us from testing for the existence of deeper organic levels in this lake. The dates obtained for the organic levels in the lakes of Cerca Grande and Sumidouro coincide roughly with the "peaks" of human burials inside the shelters, showed in Figure 2. Several limestone outcrops in the region, where the archaeological shelters are located, are associated with doline lakes. Some of these outcrops show ancient watermarks in their vertical walls. The heights of the marks in the walls attest to times of great humidity in the past. This suggests that the local lakes, mainly the doline lakes, could have been more permanent during certain periods in the past, when compared to modern times. As such, they could have been very attractive places for more permanent and denser human settlement, in a region otherwise limited by water supply for humans, animals, and vegetation.

\section{Rockshelters, archaeological "gaps", and paleoenvironments in central Brazil}

The recognition of the "Archaic Gap” at Lagoa Santa led us to search for possible correlates in adjacent areas. A survey of the archaeological bibliography for central Brazil from the last two decades resulted in a picture that seems to corroborate a broader pattern of human regional abandonment during the early and mid-Holocene in several places. Most examples come from rockshelters, which have a greater probability of being repeatedly

\section{Dates for Lagoa Santa Human Skeletons (Bone Collagen)}

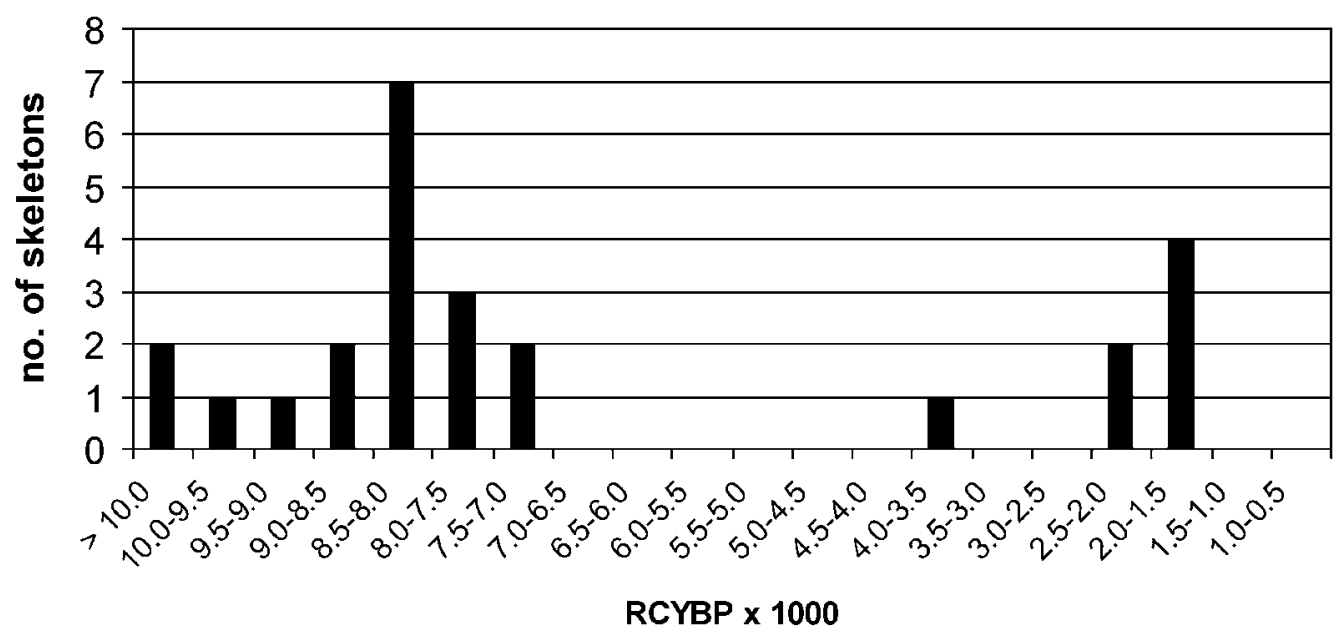

Fig. 2 - Frequency of radiocarbon ages for human skeletons from Lagoa Santa region, 500 year intervals (uncalibrated). 
ARAUJO, A.G.M.; PILÓ, L.B.; NEVES, W.A.; ATUI, J.P.V. Human occupation and paleoenvironments in South America: expanding the notion of an “Archaic Gap”. Rev. do Museu de Arqueologia e Etnologia, São Paulo, 15-16: 3-35, 2005-2006.

visited by prehistoric populations, and which allow for comparisons across the same stratigraphic profile. Initially, it is important to expose the main shortcomings inherent to these archaeological data. First, there is a question of geological constraint: deeply stratified sites with good diachronic sequences, will be found mainly at rockshelters and caves. This means that relevant data will not be evenly distributed across the landscape. Second, it is a truism that any archaeological excavation represents a kind of destruction. Most published data has to be taken at face value, and very few studies can be crosschecked subsequently in the field. Third, if we have few dates in a given level or chronological interval, it does not mean necessarily that the archaeological site was abandoned or visited less frequently; this interpretation depends on accurate analyses of artifacts, density of refuse, and in situ observations that are outside our control. We therefore use the authors' interpretations and published dates as proxy measures of site abandonment or decrease in occupation.

We will now try to integrate the archaeological and paleoenvironmental data, taking into account the potentials and shortcomings of the different methods and approaches. Our main working hypothesis is that paleoclimatic changes were responsible for the patterns observed in the archaeological record of central/northern Brazil, also influencing the patterns of human occupation observed in other portions of the country. Specifically, water availability, with its direct and indirect impacts on human beings, could be thought of as a factor of major importance in this regard. We also suggest that archaeological sites in themselves can be good proxies of paleoenvironmental stress, adding new information to the corpus of paleoenvironmental data gathered by other fields of investigation. For reasons of space, we will not explore the details of changes in lithic industry and subsistence patterns; more details can be found in Prous and Fogaça (1999).

The sites discussed below are shown in Figure 1 , numbers in parenthesis corresponding to their location.

- In the Lagoa Santa region (1), central Minas Gerais State, several rockshelters were excavated in the last 150 years, but few were subjects of detailed archaeological research. The better known sites are Cerca Grande VI (Hurt and Blasi 1969),
Lapa Vermelha IV (Laming-Emperaire et al. 1975) and, more recently, Boleiras, Taquaraçu and Lapa do Santo rockshelters (Araujo and Piló 2005). Cerca Grande VI, Boleiras and Taquaraçu present a shallow archaeological stratigraphy (1.0 to 1.5 $\mathrm{m})$, with very old ages right on the surface. Dates for Cerca Grande VI range between 9700 RCYBP and 8000 RCYB; dates for Boleiras range between 9600 RCYBP and 140 RCYBP, and there is a major gap between 7500 RCYBP and 800 RCYBP. Taquaraçu has fewer dates up to now, ranging between 9500 and 8200 RCYBP. Lapa do Santo shows a much deeper and very complex stratigraphy, with dates ranging between 8600 RCYBP and 910 RCYBP, with some possible discontinuities in occupation. Lapa Vermelha IV shows a completely different pattern, with deep stratigraphy and apparently continuous occupation, and will be discussed later.

- Santana do Riacho rockshelter (Prous 1991), located in central Minas Gerais State (2) and not very far from Lagoa Santa, provided 31 radiocarbon dates that cluster into two peaks: one between 8000 and 9500 RCYBP, and other between 4300 and 800 RCYBP (Chausson and Délibrias 1993). The human remains at the rockshelter show the same clustering: of 48 individuals found in the shelter, 40 were buried between 11,000 RCYBP and 8400 RCYBP and the remaining eight were buried between 3000 and 2000 RCYBP (Kipnis 2002).

Comments: The archaeological record at Lagoa Santa (1) and Santana do Riacho (2) suggest a decrease in human occupation between ca. 7500 RCYBP and 2000 RCYBP, and between ca. 8000 RCYBP and 4000 RCYBP, respectively. The nearest corresponding paleoenvironmental data come from Lagoa Santa, Lagoa dos Olhos, Lago Silvana and Lago do Pires. These data strongly support a climatic explanation for the decrease in the prehistoric occupation of the two areas. De Oliveira (1992) has found a high frequency of charcoal from around 7500 RCYBP (interpolated age) in the sediments at Lagoa dos Olhos, suggesting the occurrence of natural fires due to a drier climate. At Lagoa Santa, Parizzi (1993) detected very poorly preserved pollen in lake sedimentary levels dated to $5020+/-50$ RCYBP. The author suggested that drier 
ARAUJO, A.G.M.; PILÓ, L.B.; NEVES, W.A.; ATUI, J.P.V. Human occupation and paleoenvironments in South America: expanding the notion of an “Archaic Gap”. Rev. do Museu de Arqueologia e Etnologia, São Paulo, 15-16: 3-35, 2005-2006.

conditions could have been the factor damaging the pollen grains. According to Parizzi (1993), the landscape in the Lagoa Santa region during the mid-Holocene was predominantly open, with much more grass than arboreal species.

For the Late Holocene, Parizzi (1993) (Parizzi 1993) has found that between circa 3000 and $1800 \mathrm{BP}$ (interpolated age), 32\% of the pollens pertain to arboreal species, in marked contrast to what she found for the mid-Holocene. The author argues that this indicates the presence of exuberant vegetation in the region, due to elevated year-round humidity during this period. De Oliveira (1992) also found evidence of cold and humid weather for Lagoa dos Olhos between ca. 4000 (interpolated age) and 1320 BP, based on paleopalinological studies of lake sediment. The record at Lago do Pires (Behling 1998) shows a deeper chronology, where it is possible to observe an increase in moisture that starts somewhere between 8800 RCYBP and 7500 RCYBP, followed by drier mid-Holocene conditions, as detected at Lagoa Santa and Lagoa dos Olhos. At Lagoa Silvana (Rodrigues-Filho et al. 2002) it is possible to observe the transition from the dry late Glacial to the moister early Holocene around 8500 RCYBP. The same trend was observed at Salitre (Ledru 1993), $280 \mathrm{~km}$ away from Lagoa Santa towards the west.

- Lapa do Boquete rockshelter (3), located in northern Minas Gerais State, yielded several radiocarbon dates, some of them going back to the late Pleistocene (Fogaça 2001). Although the site was not completely abandoned during the midHolocene, it was much less frequently occupied: of 38 dates obtained, only five fall in the period between 7300 RCYBP and 2400 RCYBP.

- Lapa do Dragão rockshelter (4), also in northern Minas Gerais State, showed a gap between 10,000 RCYBP and 2000 RCYBP. Dates that could be considered pertaining to the Archaic (e.g., $3530 \pm 100$ RCYBP; $4040 \pm 60$ RCYBP; $5000 \pm 800$ RCYBP) were considered contaminated by the authors (Prous et al. 1997:152).

- Lapa Pequena rockshelter (5), located in northern Minas Gerais State, yielded nine dates ranging from 8240 RCYBP to 530 RCYBP (Bryan and Gruhn 1978), with a discontinuity between
7000 RCYBP and 530 RCYBP. The lower stratigraphic level, $160 \mathrm{~cm}$ thick, showed high density of artifacts ( $73 \%$ of all artifacts recovered) and was deposited over a relatively short period of time (around 700 years). In contrast, the $70 \mathrm{~cm}$ of sediment deposited in the upper level was deposited during an interval of 7500 years. This strongly suggests that human activity had a major role in the rate of sediment accumulation.

Comments: Since there are no paleoenvironmental data for the northern portion of Minas Gerais State, the correlation is restricted to the archaeological sites. However, the pattern seems to follow the trend already observed in the central region. Prous (1997) suggests that an increase in the number of “mocó” bones (rock cavy - Kerodon rupestris) found at rockshelters in northern Minas Gerais reflects an increase in aridity during the midHolocene.

Archaeological data at Lapa Pequena (5), about $350 \mathrm{~km}$ north of Lagoa Santa region, suggests a decrease in human occupation between 7000 RCYBP and 530 RCYBP, in good agreement with data coming from Lapa do Varal (8300 RCYBP to 2600 RCYBP), Boqueirão Soberbo (8200 RCYBP to 1300 RCYBP), and Barreirinho rockshelters (7600 RCYBP - ?) (7), located $80 \mathrm{~km}$ to the north. The same can be said for data coming from Lapa do Boquete (3) and Lapa do Dragão (4). At Boquete, the decrease in occupation spans from ca. 7000 RCYBP to 2000 RCYBP. At Dragão there seems to be a gap from 10,000 RCYBP to 5000 RCYBP, or, if the dubious dates are dismissed, until as late as 2000 RCYBP.

- Gruta do Gentio II, a rockshelter located in Unaí (6), northwestern Minas Gerais State, showed four discrete occupation levels (Bird et al. 1991; Dias Jr. 1991; Machado 1990). The lower three levels were dated between 10,190 \pm 120 RCYBP, and $6980 \pm 70$ RCYBP “with about ten intermediary dates” (Dias Jr. 1991:66); the upper level was bracketed between $3490 \pm$ 120 RCYBP and $410 \pm 60$ RCYBP. In the same region, Lapa da Foice rockshelter was first occupied by $7910 \pm 105$ RCYBP (SI-4495), and after almost 3500 years of abandonment the human occupation was resumed ca. 4200 RCYBP (Dias Jr. 1991:70). 
- At Varzelândia, northern Minas Gerais State (7), at least three rockshelters showed gaps in the archaeological sequence (Dias Jr. 1991). Lapa do Varal showed two discrete archaeological levels: the earliest was dated between 10,000 RCYBP and 8300 RCYBP, and the later ca. 2600 RCYBP. Boqueirão Soberbo rockshelter followed the same pattern, with the early horizon dated between 9135 \pm 167 RCYBP (SI-5508) and $8185 \pm 75$ RCYBP (SI-4487), and the late horizon ca. 1300 RCYBP. Barreirinho rockshelter showed an early archaeological horizon dated between $8845 \pm 90$ RCYBP (SI5511) and $7655 \pm 110$ RCYBP (SI-5513). It is not clear from the publication if this rockshelter also shows a late occupation level.

Comments: In the northwestern portion of Minas Gerais, Gruta do Gentio II (6) was first occupied ca. 10,000 RCYBP, and the authors suggest a decrease in occupation between ca. 7000 RCYBP and 3500 RCYBP. For Lapa do Foice the same occurs between ca. 7500 and 3500 RCYBP. These interpretations are not in agreement with the paleoenvironmental interpretation for Vereda de Águas Emendadas (Barberi et al. 2000), about $150 \mathrm{~km} \mathrm{NW}$. At that location the authors found a "drastic decrease in concentration and diversity of palynomorphs from ca. 21,000 yr BP until $7220 \pm 50$ yr BP” (op. cit.: 241), followed by an increase in moisture with a peak ca. 5600 RCYBP. At Lagoa Bonita, $10 \mathrm{~km}$ away from Águas Emendadas, data gathered by Barberi (2001) seems to match more closely the archaeological scenario, with evidence of aridity between 19,000 RCYBP and 13,000 RCYBP (based on a sedimentation hiatus) followed by an increase in moisture but in an oscillatory manner. From 13,000 RCYBP to 8400 RCYBP there was a savanna vegetation, followed by a drier period between 8400 and 6300 RCYBP. The lake was completely dry ca. 7900 RCYBP (extrapolated age). Although the interpretation for ca. 6300 to 3200 RCYBP is of a wetter climate following the first appearance of Mauritia pollen, the core showed other evidence of dryness ca. 5300 RCYBP. Modern conditions were established from 3200 RCYBP. In our view, two main factors could be responsible for the discrepancy in interpretation between these two nearby studied areas: either microclimatic differences induced by orographic factors, or problems related to the interpolation of dates. At Águas Emendadas, for example, there is an interpolation between 21,400 \pm 100 RCYBP and $7220 \pm 50$ RCYBP, missing the interval where we would expect the early Holocene moisture peak; and again, between $7220 \pm 50$ RCYBP and $2600 \pm 60$ RCYBP, introducing uncertatinty regarding the hypothesis of increasing moisture up to 5600 RCYBP.

- At Serranópolis, Goiás State (8), excavations at GO-JA-1 rockshelter produced 13 dates ranging from 10,500 RCYBP to 1000 RCYBP (Schmitz et al. 1989). The rockshelter was continuously occupied from 10,500 to 7000 RCYBP, showing a marked discontinuity thereafter (Schmitz 1980). Human occupation was resumed only about 1000 RCYBP.

Comments: GO-JA-01 rockshelter (8) was first occupied ca. 10,500 RCYBP, and shows a possible gap in human occupation between 6700 RCYBP and 1000 RCYBP. The closest paleoenvironmental study was undertaken at Cromínia (Salgado-Labouriau 1997), 300 km NE from the rockshelter, too distant to warrant correlations. However, it is worth noting that in Cromínia at $6680 \pm 90$ RCYBP are attested the lowest concentrations of algae remains and pollen grains, and high concentrations of charcoal particles (Salgado-Laboriau et al. 1997:219).

- In western Mato Grosso State, MT-GU-01, also known as Abrigo do Sol rockshelter (9) was almost totally excavated (Miller 1987). The stratigraphy shows a gap between 5800 RCYBP and 300 RCYBP, with a continuous occupation possibly reaching 14,500 RCYBP.

Comments: MT-GU-01 rockshelter (9) is the westernmost site of our sample. However, lack of paleoenvironmental studies nearby precludes any comparison.

\section{- Excavations at BA-RC-28 (Morro} Furado rockshelter), in western Bahia State (11), showed a stratigraphy with a supposed erosion event that "washed away the Archaic level” (Barbosa 1991:35). Three test-pits were dug inside the sheltered area, providing dates 
ranging from 950 RCYBP to 9100 RCYBP (Schmitz et al. 1996). Some dates between 16,000 and 26,000 RCYBP were obtained for this site, but their association with human activities is not very clear.

- Abrigo do Pilão rockshelter (12), in the central part of Bahia State, yielded dates ranging from 9600 to 800 RCYBP (Bryan and Gruhn 1993). The clustering of dates suggest abandonment during the mid-Holocene, with a gap between 8800 RCYBP and 860 RCYBP.

Comments: In Bahia State, the two sites under examination are far away from each other (about $350 \mathrm{~km}$ ), and few paleoenvironmental studies are available. BA-RC-28 rockshelter (11) shows an apparent gap between 6800 RCYBP and 2000 RCYBP. This site is relatively close (ca. $100 \mathrm{~km}$ ) to the already mentioned Lapa do Boquete and Lapa do Dragão, and seems to follow the same chronology of abandonment. Abrigo do Pilão rockshelter (12) shows a gap between 8800 RCYBP and 860 RCYBP. The closest paleoenvironmental data come from Toca da Boa Vista (Auler and Smart 2001), located $150 \mathrm{~km} \mathrm{NE}$, and from the Icatu river (De Oliveira et al. 1999), 150 km NW. From Toca da Boa Vista comes evidence of a wet climate until 9000 RCYBP, in agreement with the archaeological data. The Icatu data suggests moisture between 11,000 RCYBP and 8900 RCYBP, followed by an increase in aridity with a semi-arid peak between 6800 and 6200 RCYBP, which also agrees with the archaeological data. There is a discrepancy only in the late-Holocene, when Icatu paleoclimatic data suggest an increase in moisture between 6200 and 4500 RCYBP.

- Furna do Estrago rockshelter (13), in Pernambuco State, also showed a gap in the ages obtained; the rockshelter was first occupied at 11,000 RCYBP, and there is no human occupation between 8500 RCYBP and 1000 RCYBP (Lima 1985; Lima 1991).

- Several rockshelters excavated in the São Raimundo Nonato area (14), Piauí State, also suggest a discontinuity in human occupation. At Boqueirão da Pedra Furada, all dates are older than 6000 RCYBP (Parenti 2001). At Toca do Sítio do Meio, dates range between 20,000
RCYBP and 8800 RCYBP. At Caldeirão do Rodrigues I, the most recent date is 7600 RCYBP. At Toca da Boa Vista I dates range between 9700 RCYBP and 5000 RCYBP. At Toca do Bojo the archaeological sequence spans from 9700 RCYBP to 7000 RCYBP. At Toca da Barra do Antonião dates show a discontinuity in the use of the rockshelter between 6000 RCYBP and 2000 RCYBP This trend can be observed in tables presented by Martin (1997). The only exception is found at Baixão do Perna I, where an apparently continuous occupation is suggested by the dates obtained, spanning from 10,500 RCYBP to 3800 RCYBP (Martin 1997).

Comments: To our knowledge, there are no paleoenvironmental data in the vicinities of Furna do Estrago rockshelter (13). As already noted, data coming from São Raimundo Nonato (14), Piauí State, suggest moister and cooler climate between 8700 RCYBP and 7000 RCYBP (Chaves 2000). Most rockshelters were abandoned ca. 7000 RCYBP and some were reoccupied only ca. 2000 RCYBP, suggesting a regional abandonment in the mid-Holocene followed by a return of people after moister conditions occurred again.

\section{Southern Brazil: no gaps?}

Southern Brazil, considered here as the southern portion of São Paulo State and the states of Paraná, Santa Catarina and Rio Grande do Sul, is very heterogeneous in terms of archaeological research and results. Rio Grande do Sul, Santa Catarina and Paraná are fairly well known. In contrast, huge portions of São Paulo lack even a single piece of archaeological information. Overall, the region does not contain many well-dated rockshelters, and the kind of comparison carried out for the other regions of the country is thus hampered. Distribution of sites across the landscape suggests that Paleoindians were present since at least ca. 11,000 RCYBP at both the northern and southern extremes of the region (Rio Grande do Sul and central São Paulo - Beltrão et al. 1986; Dias and Jacobus 2000; Dias and Jacobus 2001; Miller 1987). In São Paulo, the only sites within the 11,000 - 10,000 RCYBP range are Alice Böer (Beltrão et al. 1986), and Capelinha 1 (Lima 2005) 
with bifacial projectile points that place them in closer affiliation with the southern industries. By 9800 RCYBP, rockshelters in the eastern portion of the state, relatively close to the sea, were first occupied (Collet 1985; De Blasis 2001). The inland portion of São Paulo shows dates ranging from 7000 RCYBP to present (Vilhena-Vialou 1984). Due to the poor archaeological data for the state, it is not possible to know if there is actually a gap between ca. 8500 RCYBP and 7000 RCYBP. In environmental terms, São Paulo could be regarded as a transitional area between central Brazil and the southern region, and therefore the lack of data frustrates any attempt to understand past human settlement strategies in this important region during the mid-Holocene.

Paraná State shows a continuous record of human occupation since 7000 RCYBP (Chmyz 1983), and the same perhaps can be said for Santa Catarina. Rio Grande do Sul, the better studied region, shows a continuous archaeological record from 11,000 RCYBP up to the present (Noelli 2000).

When viewed in the light of paleoenvironmental data, the human occupation of southern Brazil seems to be significantly more unconstrained in terms of moisture/temperature/seasonality than the rest of Brazil. In fact, the region probably showed a milder climate when compared to both central Brazil (due to water availability) and meridional settings such as the Argentinian Pampas (in this case due to low temperatures and water availability). The climate became moister and warmer through the Holocene, explaining the region's more stable human occupation, without marked gaps. If the palynological data for Santa Catarina coast can be extrapolated (Behling and Negrelle 2001), rainforest was starting to develop very early, since 12,300 RCYBP, and therefore paleoclimatic conditions were probably suitable for human occupation. The coastal area would therefore be very attractive to Paleoindian groups, as suggested by the early dates already generated for the coastal mountain range (“Serra do Mar” - Collet 1985).

\section{Other evidence of regional Holocene human abandonment in South America}

Perhaps the best documented case of regional human abandonment in prehistoric times for South
America is that recorded at Atacama Desert, northern Chile (Nuñez et al. 2001; Nuñez et al. 2002; Nuñez and Santoro 1988). Paleoenvironmental evidence coupled with extensive archaeological data showed that human occupation in the Puna de Atacama was coincident with periods of increased moisture and high paleolake levels, whereas a dry event between 8000 RCYBP and 5000 RCYBP was responsible for a gap in the archaeological record. The authors were also able to find at least one place (Quebrada de Puripica) where local conditions of moisture (natural damming of a river) created an ecological refuge, allowing human populations to survive between 6200 RCYBP and 1760 RCYBP inside a generally inhospitable environment (Nuñez et al. 1999).

The Pampas region, in northeastern Argentina, also shows a pattern that deserves consideration in the context of the present discussion. Paleoclimatic conditions for the Pampean region are still under debate (Iriondo 1997; Prieto 1997). Some authors suggest dry mid-Holocene conditions (Prieto 1996), while others interpret the record as evidencing a moister mid-Holocene climate (from 8500 RCYBP to 3500 RCYBP), based on the concept of “Climatic Optimum” or Hypsithermal (Iriondo 1999; Kröhling 1999; Kröhling and Iriondo 1999). The region probably had a very heterogeneous climate since the Late Pleistocene (Politis and Madrid:748), which may explain in part the different paleoclimatic interpretations. Nevertheless, some of the sites in the region show certain evidence of abandonment, such as the case of Cueva Tixi (Mazzanti 1997; Mazzanti 1996), in the Tandilia region, with two early Holocene dates for the first occupation (Level 1: 10,375 \pm 90 RCYBP and $10,045 \pm 95$ RCYBP), followed by a gap, a subsequent occupation in the mid-Holocene (4865 \pm 65 RCYBP and $3255 \pm 75$ RCYBP), and later occupation only in proto-historic times (715 \pm 45 RCYBP and $170 \pm 60 \mathrm{BP}$ ). In the nearby Abrigo los Pinos, $5 \mathrm{~km}$ from Cueva Tixi, three dates also put the first occupation in the same interval (10,465 \pm 65 RCYBP; 10,415 \pm 70 RCYBP; $9570 \pm 150$ RCYBP). Cueva El Abra, also in the Tandilia range (Mazzanti 2004), showed two distinct occupation levels: the lower component dated to $9834 \pm 65$ RCYBP, and the upper component to $958 \pm 32$ RCYBP, with no human occupation in between. At Cerro El Sombrero Abrigo 1, there is an early Holocene occupation between 10,725 \pm 90 
RCYBP and $8060 \pm 140$ RCYBP, and at Cerro La China 1, dates fall between 10,804 \pm 75 RCYBP and 10,525 \pm 75 RCYBP (Flegenheimer and Zárate 1997).

In the Central Andes of Argentina, research at Agua de la Cueva rockshelter (García et al. 1999) showed an initial settlement around 11,000 RCYBP, and intense use of the rockshelter until 9000 RCYBP. Between 9000 RCYBP and 5000 RCYBP, the site was scarcely occupied due to increasing aridity: in the 2000 radiocarbon years span comprising the initial occupation, the authors found 732 artifacts and 16,071 debitage; in the remaining 4000 years of aridity, they found only 126 artifacts and 2448 debitage (op. cit:49 - but see a different view regarding a hiatus in the midHolocene for this area in García 2005).

In NW Argentina a similar pattern was observed at Inca Cueva 4, with an early occupation at 10,620 \pm 140 RCYBP, lasting until $9230 \pm 70$ RCYBP, followed by a gap and a later date of $5200 \pm 110$ RCYBP. The gap is related to the same arid interval detected at Atacama (Nuñez et al. 1999).

In the same region, Pintoscayoc -1 was first occupied at 10,720 \pm 150 RCYBP, with several dates spanning a period of 1700 radiocarbon years up to $9080 \pm 50$, and a later date of $7850 \pm 110$ $\mathrm{RCYBP}$. The area was reoccupied again only at 2900 RCYBP, coincident with the period of increased moisture identified at Laguna Miscanti (Grosjean et al. 2001, Nuñez et al. 1999).

Also in NW Argentina, in Southern Mendoza province, Gil et al. (2005) detected a gap in the regional archaeological record, spanning from about 7000 RCYBP to 4000 RCYBP, in accordance with paleonvironmental data that suggests an increase in dryness.

\section{Out of the shelters: regional patterns inferred from open-air sites}

Up to this point we have dealt only with evidence coming from rockshelters, which exhibit a very clear pattern of mid-Holocene abandonment or decrease in occupation. Nevertheless, regional comparisons between rockshelters and open-air sites are a good way to test our proposition. This comparison depends, of course, on data coming from archaeologically well-known areas, with abundant dated sites and good survey coverage.
The Argentinean Pampas are such a case, providing an excellent corpus of data for our purposes. In Brazil, however, not all regions show these characteristics, and to be sure, many of the dated sites listed in regional compilations are not geographically referenced. Our procedure for Brazil will be to assign the sites according to the state where they were found. Although this will result in an admittedly coarse spatial analysis, we would still expect to detect the regional abandonment pattern we advocate, since it is probably very broad. The assumption underlying this analysis is that the frequency of dates in a given region is a proxy measure of the density of human occupation (Rick 1987).

We deliberately avoided using data from coastal areas, since human occupation in these settings was constrained mainly by sea-level fluctuations, and early Holocene sites are probably underwater. We also did not analyze data from NE Brazil and the Amazon for other reasons: while NE Brazil has a fair number of dated archaeological sites, the paleoenvironmental setting is still far from clear, perhaps due to the extreme climatic/moisture variability already observed by other authors (Auler and Smart 2001; Nimer 1989). In the Amazon, on the other hand, the debate over the refugia hypothesis led to a greater investment in paleoenvironmental research, but the archaeological scenario is not very clear.

\subsection{Brazil: the central states}

Here we scrutinize data coming from what we call "the central states" of Brazil, a database composed of 462 radiocarbon and luminescence dates, ${ }^{1}$ distributed as follows : Minas Gerais (135 dates), Goiás (112 dates), Tocantins (26 dates), Bahia (51 dates), Mato Grosso (89 dates), and Mato Grosso do Sul (49 dates). We plotted these dates in bar graphs at 500 year intervals.

The frequency of dates for Minas Gerais (MG) is shown in Figure 3. The two-peaked aspect of the graph is easily noticed, with a marked decrease in the number of dates between ca. 7500 RCYBP and 1500 RCYBP. There are no sites dated between 5000 and 5500 RCYBP.

(1) Based mainly on Oliveira \& Viana (2000) etchevarne (2000), and Bueno (2005). 


\section{Minas Gerais}

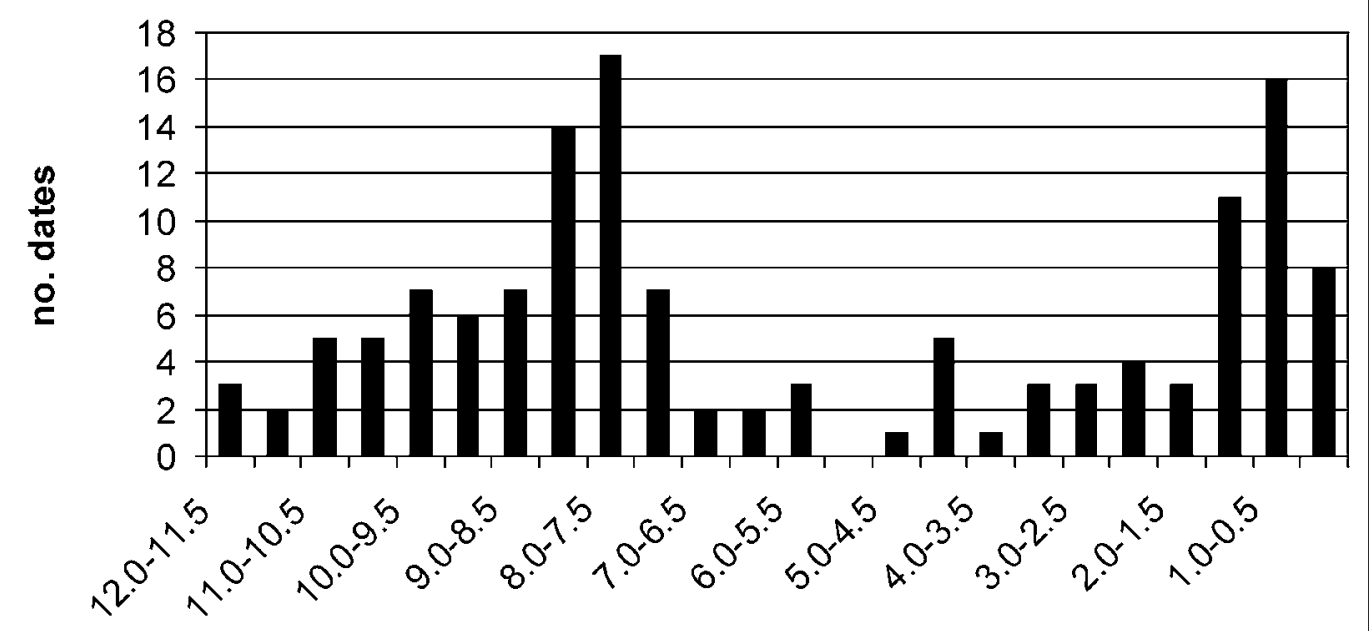

C14 yrs BP(x1000)

Fig. 3 - Frequency of radiocarbon ages for archaeological sites from Minas Gerais state (MG), 500 year intervals (uncalibrated).

Dates for Goiás (GO) are shown in Figure 4. The pattern here seems different, with an overall low frequency of dates throughout the Holocene, increasing only in the last 1500 RCYBP. Even so, Paleoindian presence is recorded since 11,000 RCYBP, and periods with no dates occur only in the mid-Holocene.

Dates for Tocantins (TO) are shown in Figure 5. It must be stressed that in this case the dates come from a somewhat restricted area, called Lajeado (number 20 in Figure 1) subject to contract archaeology (Bueno 2005). Although the sample size is much smaller, the pattern suggested by the graph shows two gaps in the chronology: one between 9000 and 6000 RCYBP, and other between 5000 and 2500 RCYBP, with a single date in the middle.

Dates for Bahia (BA) are shown in Figure 6. Although the pattern is not as clear as in other regions, the absence of sites dated in the midHolocene is again visible. It is possible that the lumping of sites from southern and northern Bahia helped blur the picture, since northern Bahia is part of the NE Brazilian badlands ("sertão"), an area with and extremely variable climate both in the past and the present (see discussion on section 2.1.2).

The frequency of dates for Mato Grosso (MT) are shown in Figure 7. Here again, the pattern is clear, with a marked decrease in dates between 5500 RCYBP and 3000 RCYBP.

Results for Mato Grosso do Sul (MS) are shown in Figure 8. Here the sample size is extremely small, but does not contradict the presence of a Paleoindian occupation followed by a period of decrease in settlements.

Plotting the 462 dates from the central Brazilian states provides an overview of the pattern occurring in central Brazil (Figure 9): two peaks in human occupation, the early one around 8000 RCYBP, the later just before the European arrival, and a period of lesser occupation in between, reaching a minimum at ca. 5000 RCYBP. In summary, these data from open-air sites corroborate those coming from the rockshelters, and are in good overall agreement with the paleoenvironmental interpretations for the region. 


\section{Goiás}

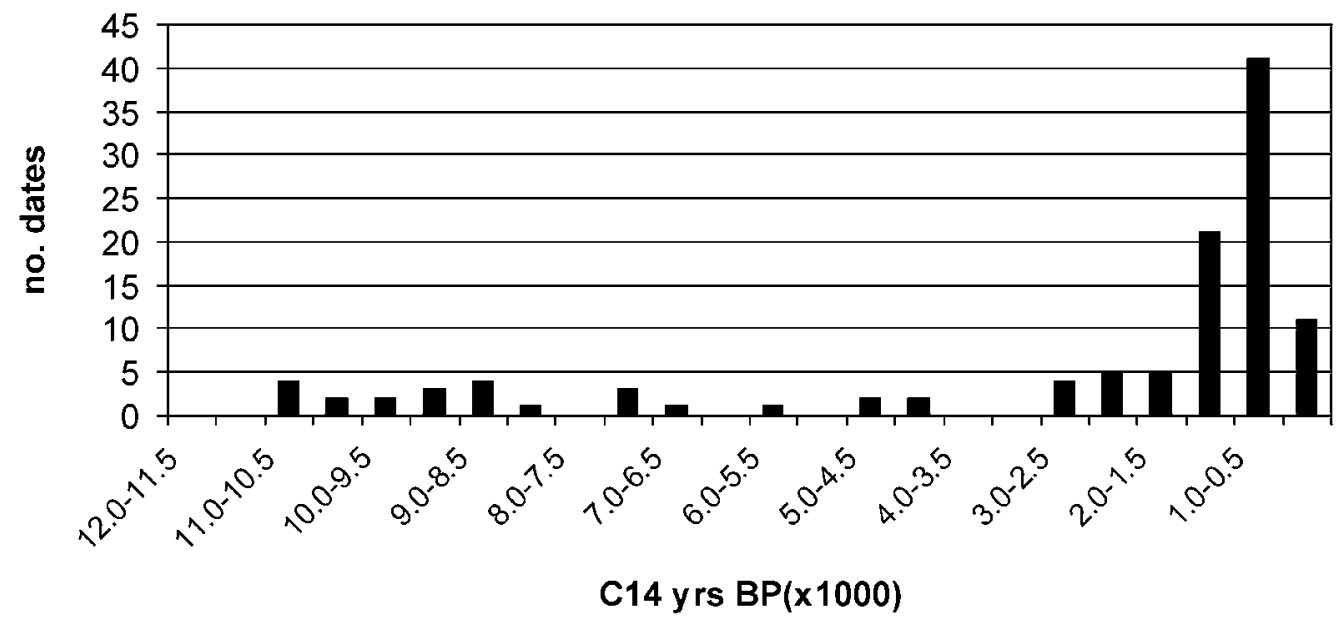

Fig. 4 - Frequency of radiocarbon ages for archaeological sites from Goiás state (GO), 500 year intervals (uncalibrated).

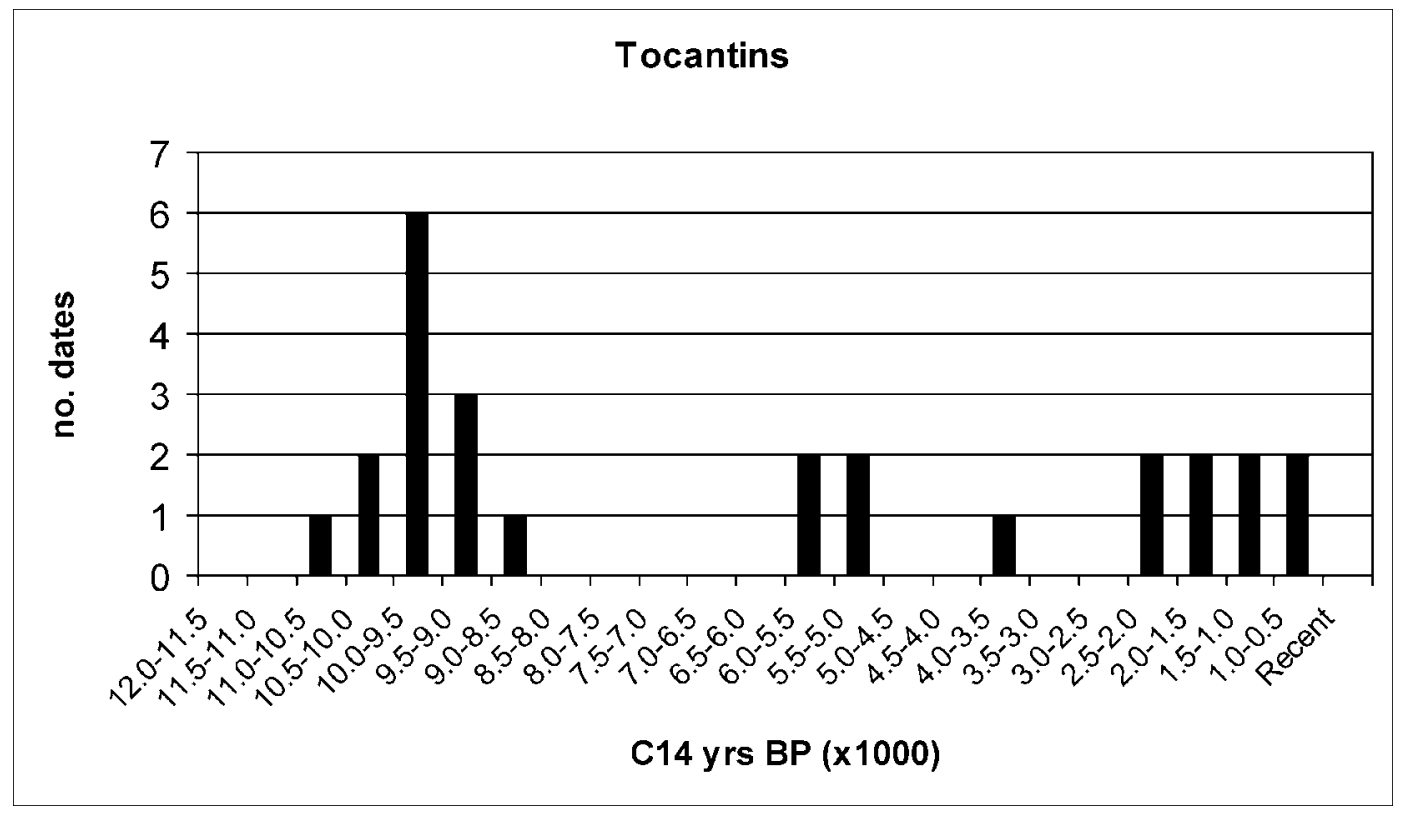

Fig. 5 - Frequency of radiocarbon ages for archaeological sites from Tocantins state (TO), 500 year intervals (uncalibrated). 


\section{Bahia}

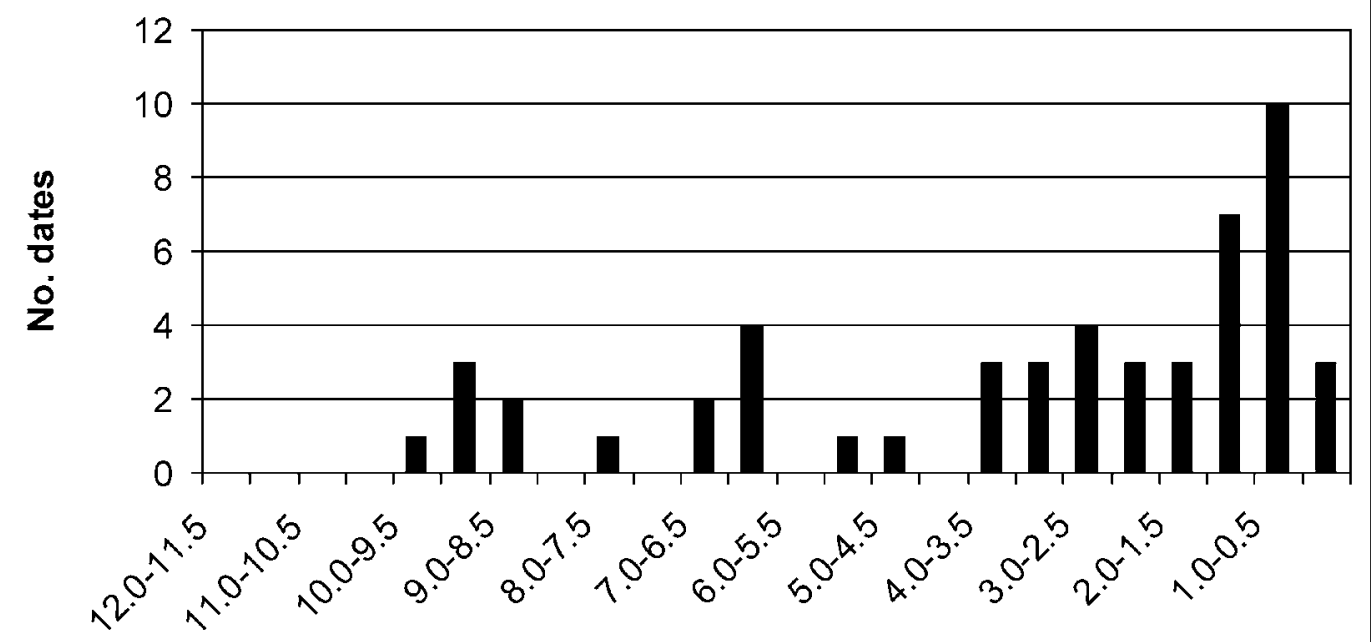

C14 yrs $B P(\times 1000)$

Fig. 6 - Frequency of radiocarbon ages for archaeological sites from Bahia state (BA), 500 year intervals (uncalibrated).

\section{Mato Grosso}

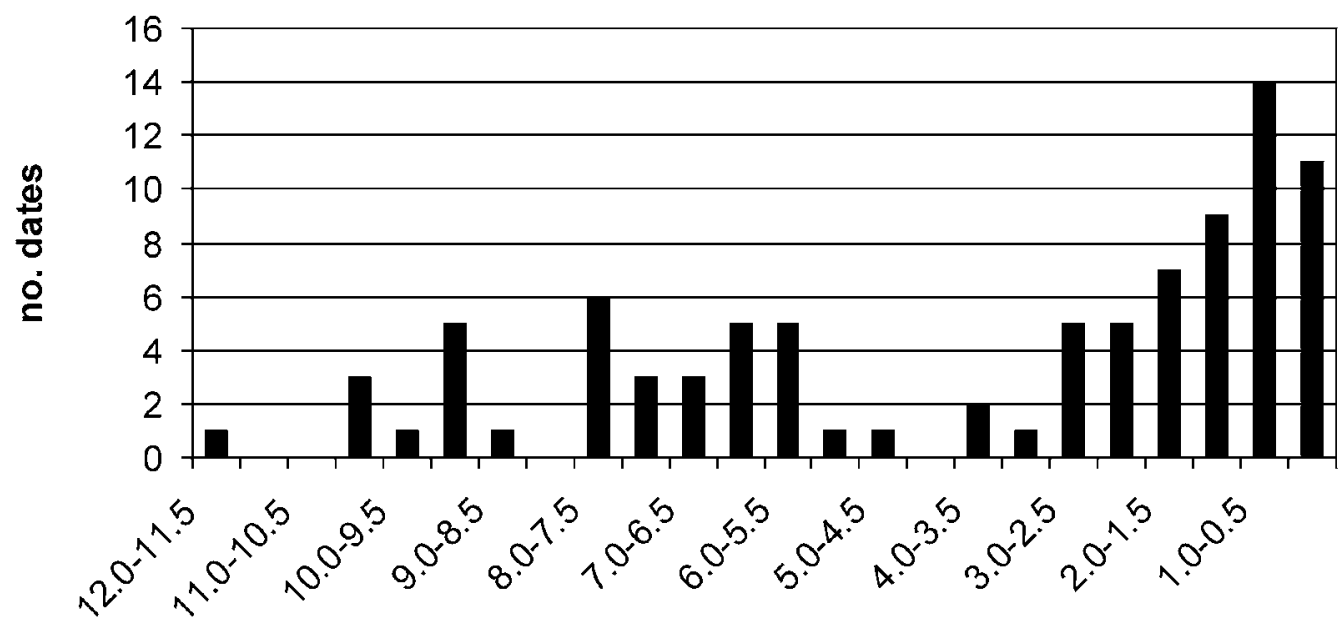

C14 yrs $B P(x 1000)$

Fig. 7 - Frequency of radiocarbon ages for archaeological sites from Mato Grosso state (MT), 500 year intervals (uncalibrated). 


\section{Mato Grosso do Sul}

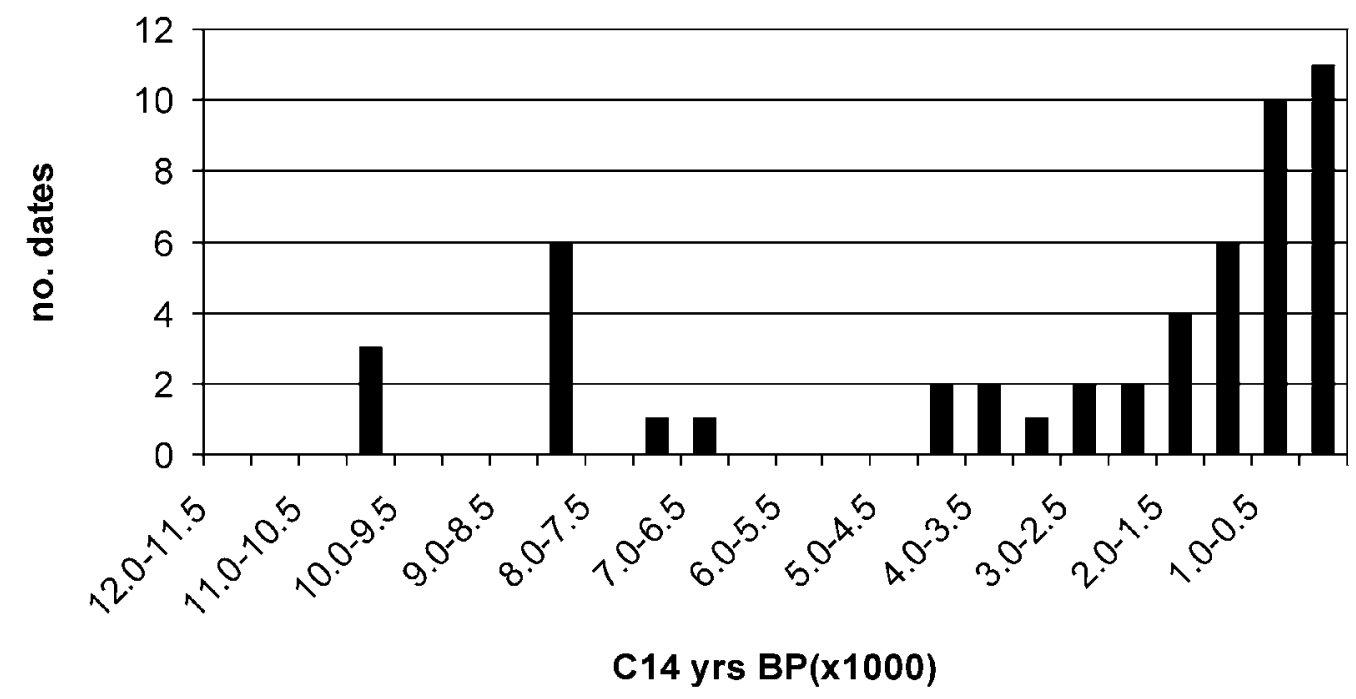

Fig. 8 - Frequency of radiocarbon ages for archaeological sites from Mato Grosso do Sul state (MS), 500 year intervals (uncalibrated).

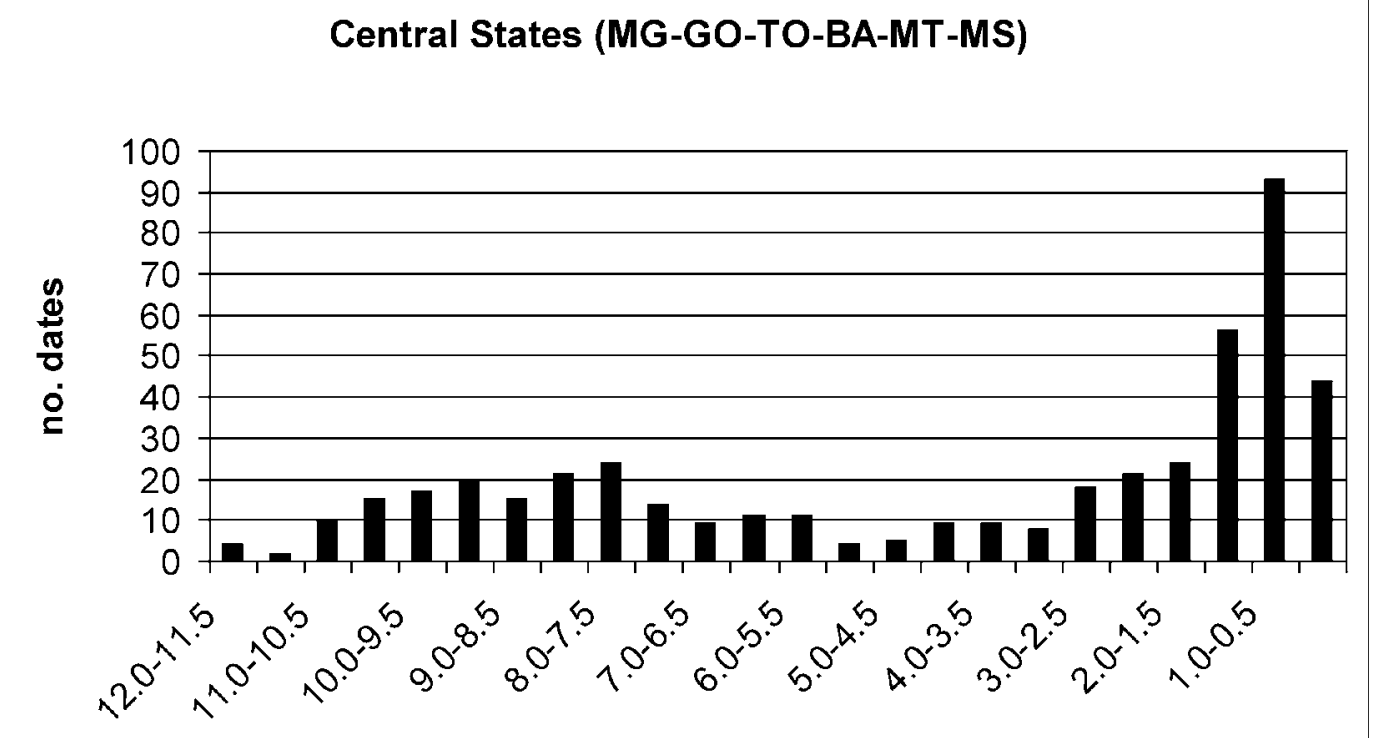

\section{C14 yrs BP(x1000)}

Fig. 9 - Total frequency of radiocarbon ages for MG, GO, BA, MT, and MS, 500 year intervals (uncalibrated). 
ARAUJO, A.G.M.; PILÓ, L.B.; NEVES, W.A.; ATUI, J.P.V. Human occupation and paleoenvironments in South America: expanding the notion of an “Archaic Gap”. Rev. do Museu de Arqueologia e Etnologia, São Paulo, 15-16: 3-35, 2005-2006.

\subsection{Brazil: the southern states}

Our database comprises 304 dates $^{2}$ for sites in the southern states, here including São Paulo (68 dates), Paraná (80 dates), Santa Catarina (28 dates), and Rio Grande do Sul (128 dates).

The frequency of dates from São Paulo can be observed in Figure 10. As we already noted, the gap between 8500 RCYBP and 7000 RCYBP may be an artifact of the sample size and poor archaeological knowledge. The general aspect of the graphic suggests a somewhat continuous increasing in the frequency of dates (no “Archaic Gap”), with an exponential increase in the last 1500 RCYBP, coincident with the appearance of ceramist groups in the region.

Dates for Paraná (PR) are shown in Figure 11. Occupation in the Holocene seems to be fairly continuous, without peaks, until ca. 1500 RCYBP when the number of dates, and probably the population, increased steeply.

Data gathered for Santa Catarina (SC) are shown in Figure 12. The sample size is too small to allow interpretations, other than to say that the probable trend of a population increase after 1500 RCYBP is maintained.

The frequency of dates for Rio Grande do Sul (RS) is shown in Figure 13. This is the best sample we have for southern Brazil, and it seems that there are at least two peaks of dates, an earlier one between 10,500 RCYBP and 9000 RCYBP, and another representing the previously observed increase ca. 1500 RCYBP. However, the twopeaked pattern is not as clear as in the central portion of the country, and indeed we could postulate a rather stable early to mid-Holocene population followed by a manifold increase in the late Holocene. This pattern is better observed if we deal with all 304 dates, as can be seen in Figure 14.

These data are also in very good agreement with the paleoenvironmental scenario proposed for inland southern Brazil: the climate became moister and hotter through the Holocene, specially after 3000 RCYBP, when Araucaria forest started to expand (Behling 1997; Behling 2002; Behling et al. 2001). Therefore, great oscillations in the local population during the mid-Holocene for this portion of Brazil would not be expected.

(2) Based mainly on Noelli (2000); Dias \& Jacobus (2000); Lima (2005); and Parellada (2006).

\subsection{Statistical comparison between central and southern Brazil}

The frequencies presented in Figures 9 and 14 respectively for Central and Southern Brazil seem fairly different on a visual basis, but a statistical analysis was used to check the results. Since the frequencies did not show a normal distribution, we had to use a non-parametric statistical test. MannWhitney's U-test was considered the most adequate in order to evaluate if the distributions of dates obtained for Central and Southern Brazil were significantly different. The results $[\mathrm{U}=53356,50$ $(p<0,0000001)]$ showed that the pattern of dates is significantly different between the two regions. Two assumptions underlie this analysis: we considered that there was no sample bias, i.e., that all archaeological sites were sampled in a similar and consistent way, and that the rates of generation and decomposition of datable material were also similar.

\subsection{Argentina: the Pampas}

The Pampean region of Argentina is one of the best places in South America to undertake the kind of comparison we seek, since it has good archaeological coverage and several dated sites, together with a vast (but sometimes conflicting) corpus of paleoenvironmental data. Also, published data for this region (Politis and Madrid 2001; Mazzanti 2002; Mazzanti 2004) allow analysis of the dates according to different environments or micro-regions, rather than lumping them. A grand total of 147 dates were tabulated for the Pampas ${ }^{3}$ and the archaeological evidence for a mid-Holocene abandonment of the region, as suggested in Section 6 , can be compared with the general trend of dates from the Area Serrana de Tandilia micro-region (AST). The already mentioned Cueva Tixi, Abrigo Los Pinos, Cerro El Sombrero and Cerro La China are all located in the AST micro-region. Figure 15 shows the frequency of dates for AST (30 dates), where it is clear that there is a gap between ca. 7500 RCYBP and 5000 RCYBP. Other important archaeological sites such as Arroyo Seco 2, Paso Otero 5, and La Moderna, all showing evidence of
(3) Based on Politis and Madrid (2001) and Mazzanti (2004). We did not use dates considered problematic by the authors. 


\section{São Paulo}

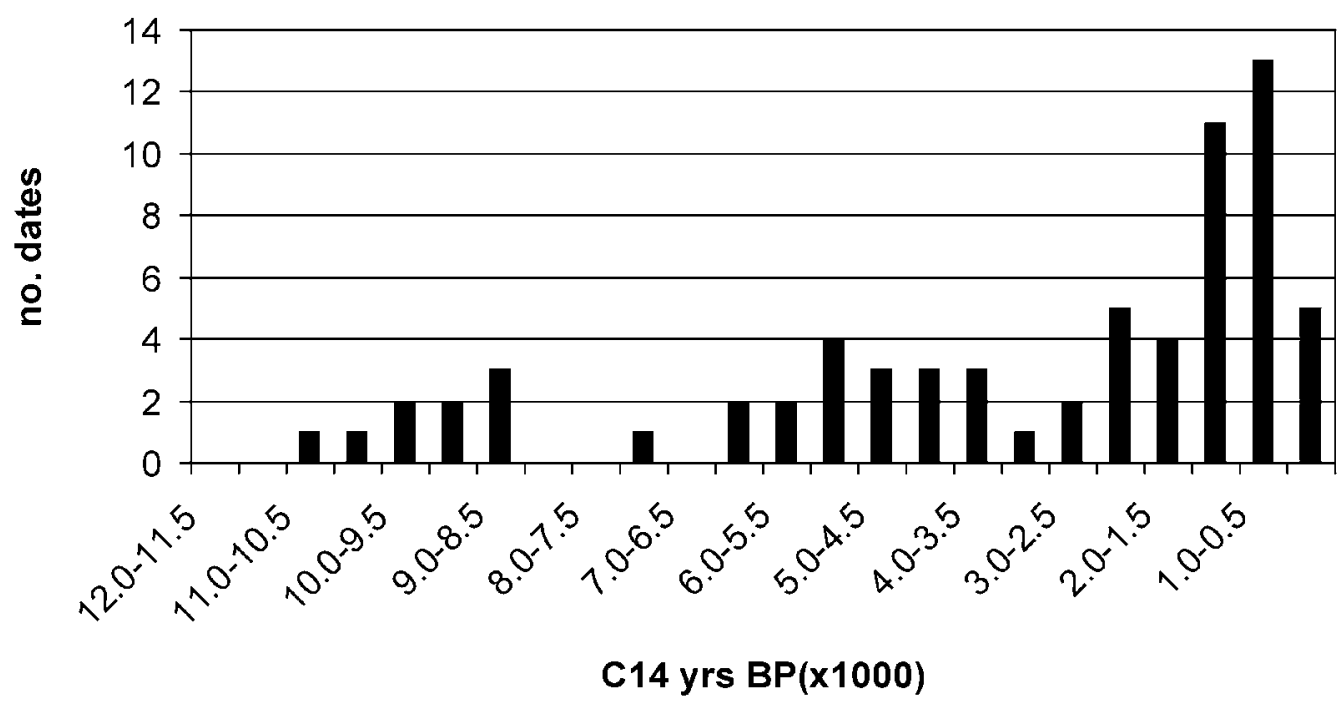

Fig. 10 - Frequency of radiocarbon ages for archaeological sites from São Paulo state (SP), 500 year intervals (uncalibrated).

\section{Paraná}

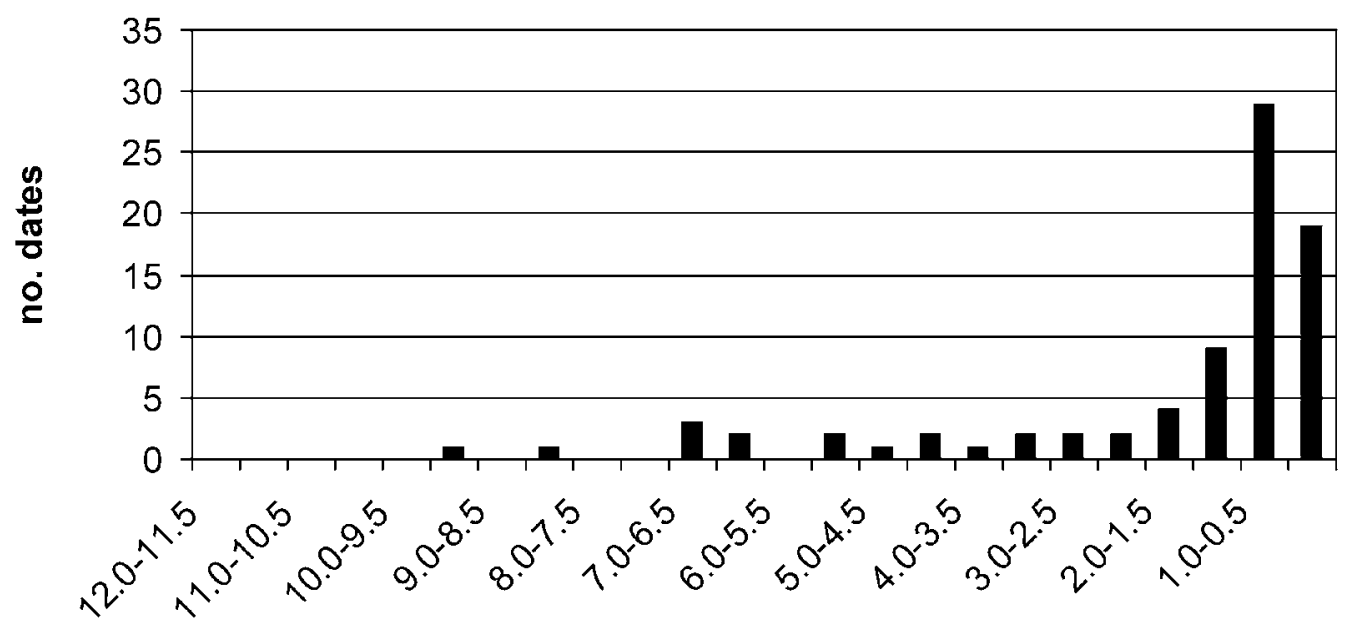

C14 yrs BP(x1000)

Fig. 11 - Frequency of radiocarbon ages for archaeological sites from Paraná state (PR), 500 year intervals (uncalibrated). 


\section{Santa Catarina}

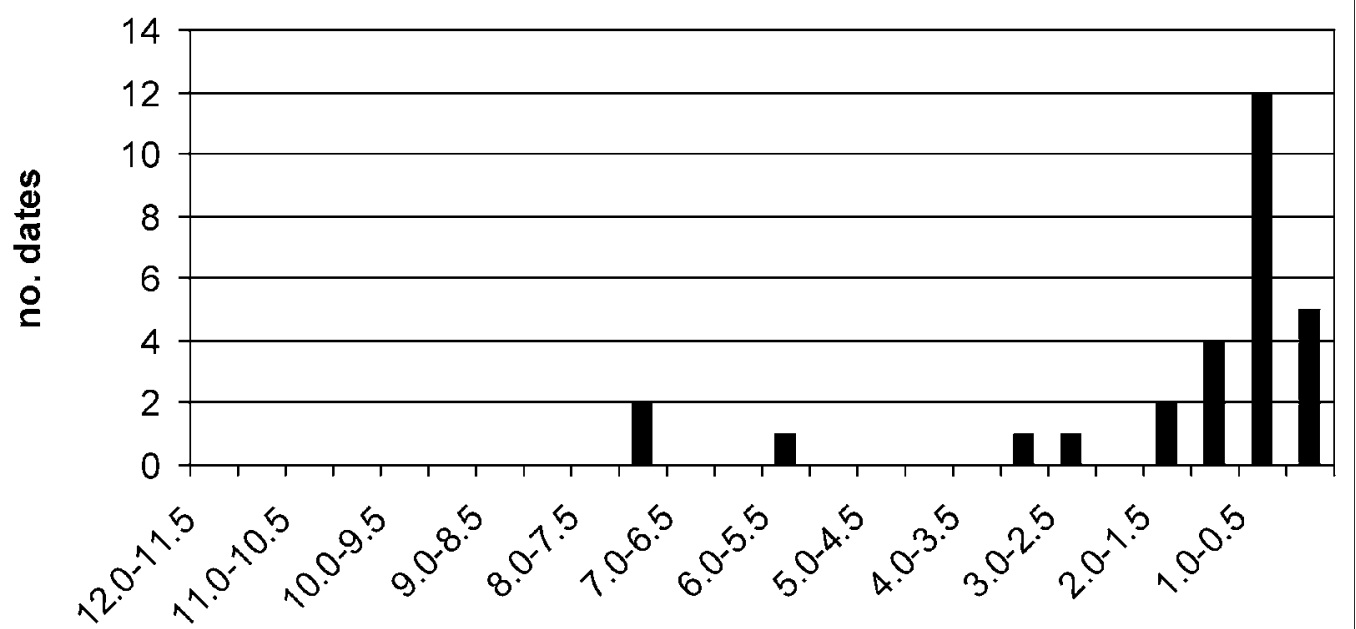

C14 yrs $B P(\times 1000)$

Fig. 12 - Frequency of radiocarbon ages for archaeological sites from Santa Catarina state (SC), 500 year intervals (uncalibrated).

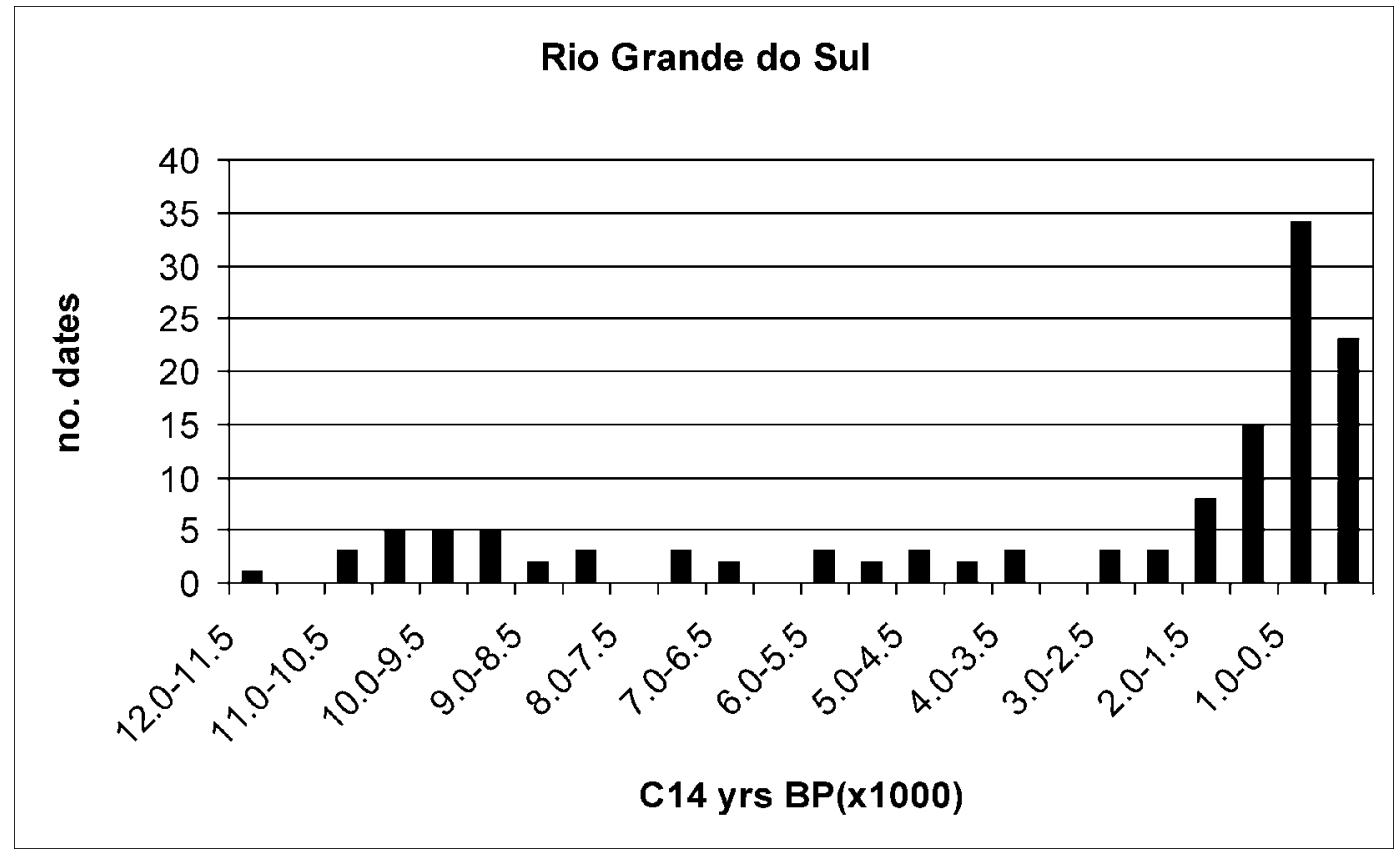

Fig. 13 - Frequency of radiocarbon ages for archaeological sites from Rio Grande do Sul state (RS), 500 year intervals (uncalibrated). 


\section{Southern States (SP-PR-SC-RS)}

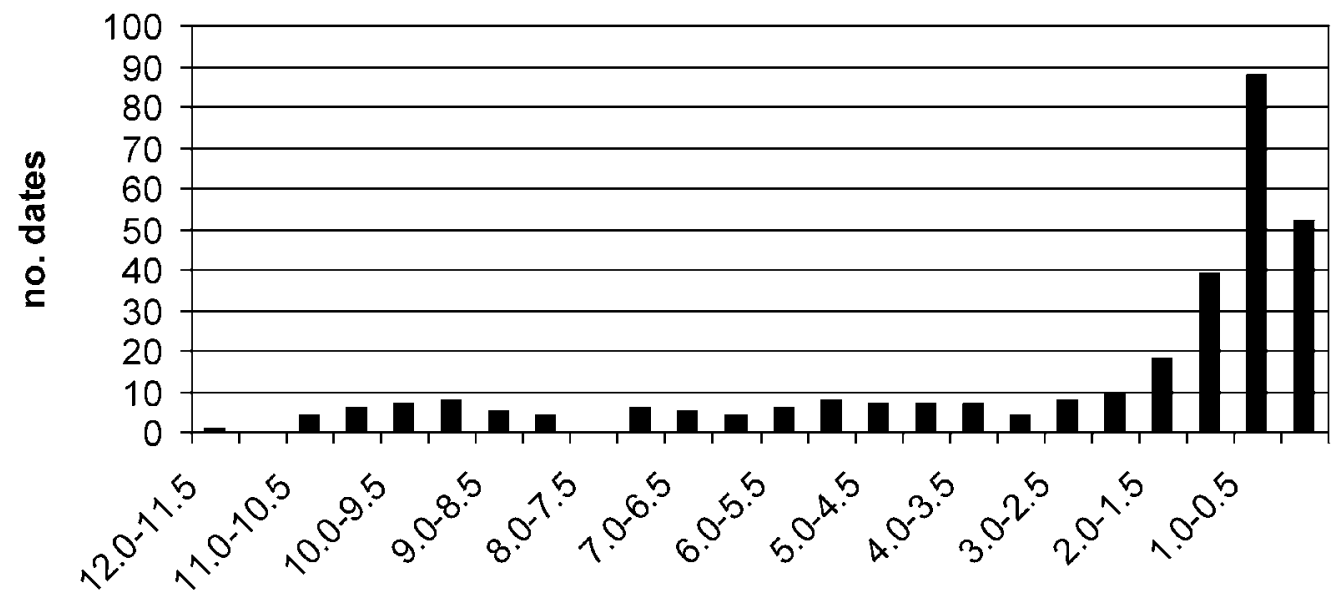

C14 yrs BP(x1000)

Fig. 14 - Total frequency of radiocarbon ages for SP, PR, SC, and RS, 500 year intervals (uncalibrated).

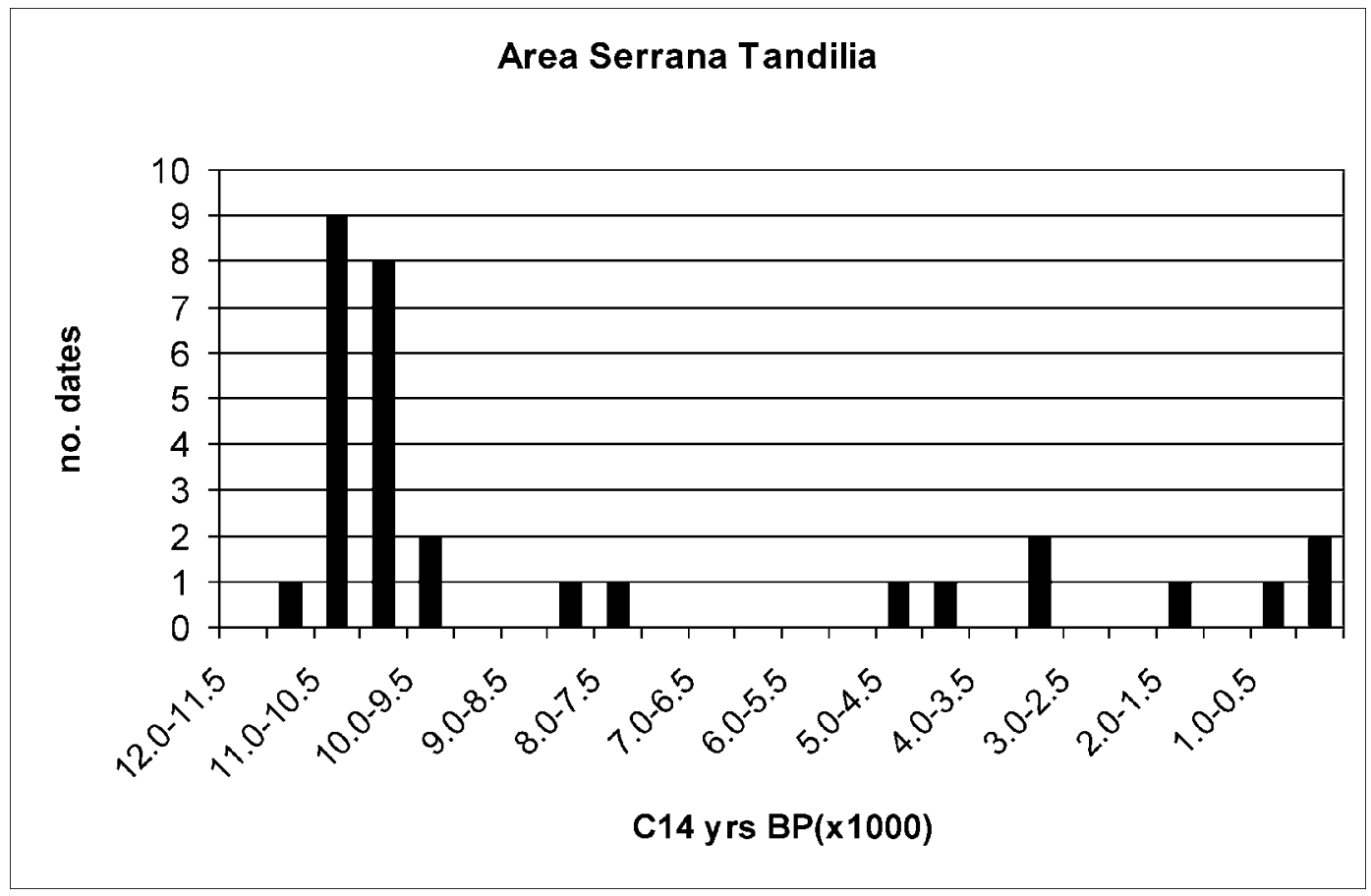

Fig. 15 - Frequency of radiocarbon ages for archaeological sites from Area Serrana de Tandillia region, Argentinian Pampas, 500 year intervals (uncalibrated). 
late Pleistocene/early Holocene occupation associated with extinct fauna, are located in the Area Interserrana micro-region (AI). Figure 16 shows the frequency of dates for AI (56 dates). It is possible to discern not one, but two gaps: the first one between ca. 10,200 RCYBP and 8800 RCYBP, the second between ca. 6000 RCYBP and 4800 RCYBP. Accordingly, there seems to be three peaks of dates, the first one in the late Pleistocene, a second, well marked peak between ca. 6500 RCYBP to 7500 RCYBP, and a third reaching its maximum ca. 2000 RCYBP to 2500 RCYBP. Other regions of the Pampas show a somewhat later occupation, as can be observed in Figures 17 to 20. All dates are ploted together in Figure 21. The three-peaked pattern is well marked, suggesting three periods of increased human occupation in the region.

If we accept the paleoenvironmental interpretations elaborated by Iriondo and colleagues (Iriondo 1999, Kröhling 1999, Kröhling and Iriondo 1999), a scenario of regional abandonment due to climatic conditions does not make sense, since these authors believe that the wettest period in the Pampas happened during the “Climatic Optimum”, between 8500 and 3500
RCYBP. However, other authors envisage a different picture. Based on mammalian assemblages, Tonni et al. (1999) believe that during the Holocene the climate in the Pampas was arid and cold, with short wetter periods. Barrientos \& Perez (2005), dealing with bioanthropological data, suggest that the gap in radiocarbon ages for archaeological sites in the Pampas between ca. 6000 and 5000 RCYBP coincides with a contraction/replacement of indigenous populations. Recent dating of paleosols in the Pampean region seems to suggest at least three periods of soil formation during the Holocene (Tonni et al. 2001), which could be assigned to moister conditions. Interval frequencies of 25 Pampean paleosol dates published by Tonni et al. (2001:125) can be observed in Figure 22. An analysis of their distribution suggests at least three periods of soil formation: between 10,000 RCYBP and 8700 RCYBP; between 7000 RCYBP and 4000 RCYBP; and between 2800 RCYBP and 1500 RCYBP. These three supposedly moister episodes are in good agreement with the archaeological trend of the occupation of the region, although the timing is not precisely the same. Dates for the

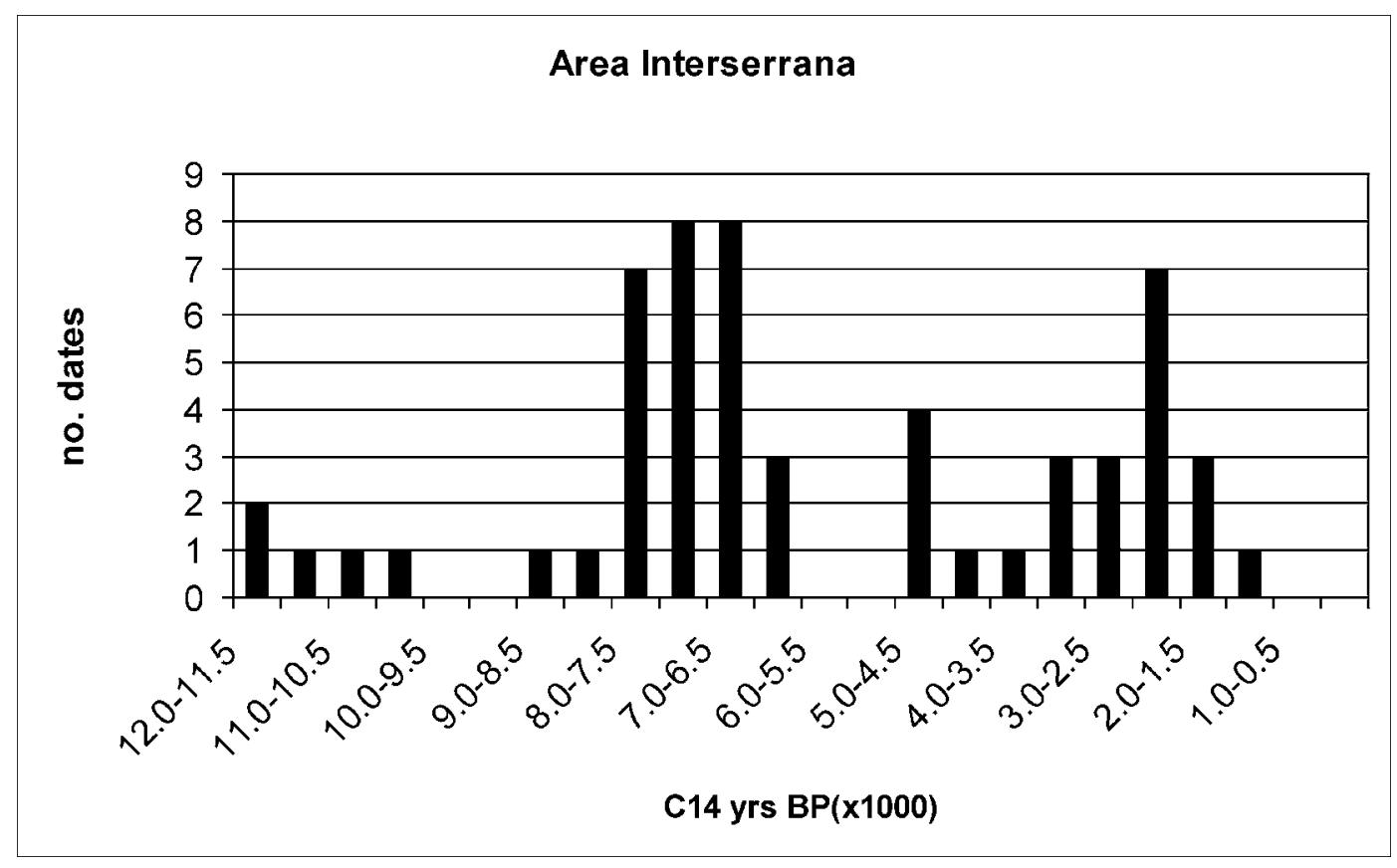

Fig. 16 - Frequency of radiocarbon ages for archaeological sites from Area Interserrana region, Argentinian Pampas, 500 year intervals (uncalibrated). 


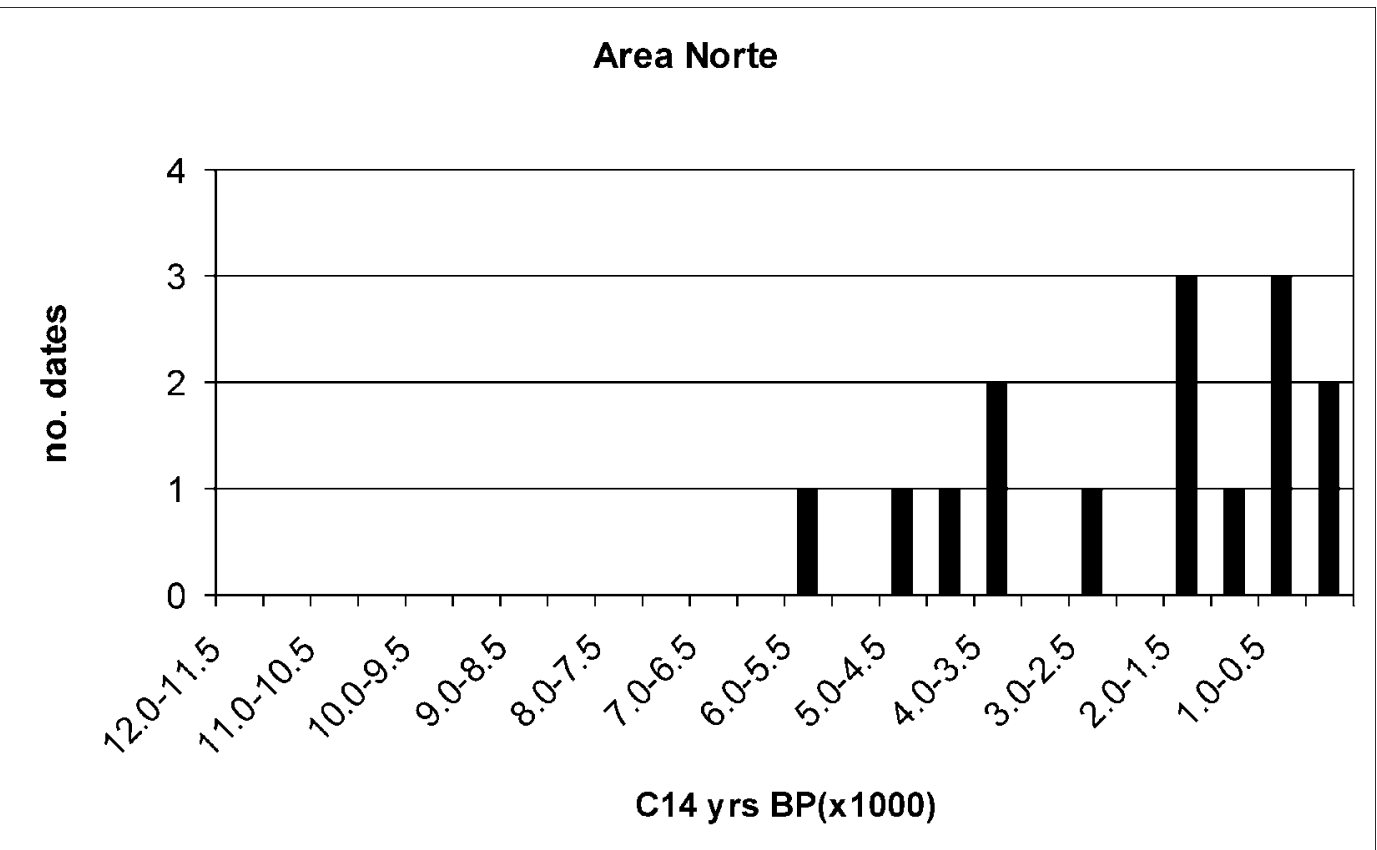

Fig. 17 - Frequency of radiocarbon ages for archaeological sites from Area Norte region, Argentinian Pampas, 500 year intervals (uncalibrated).

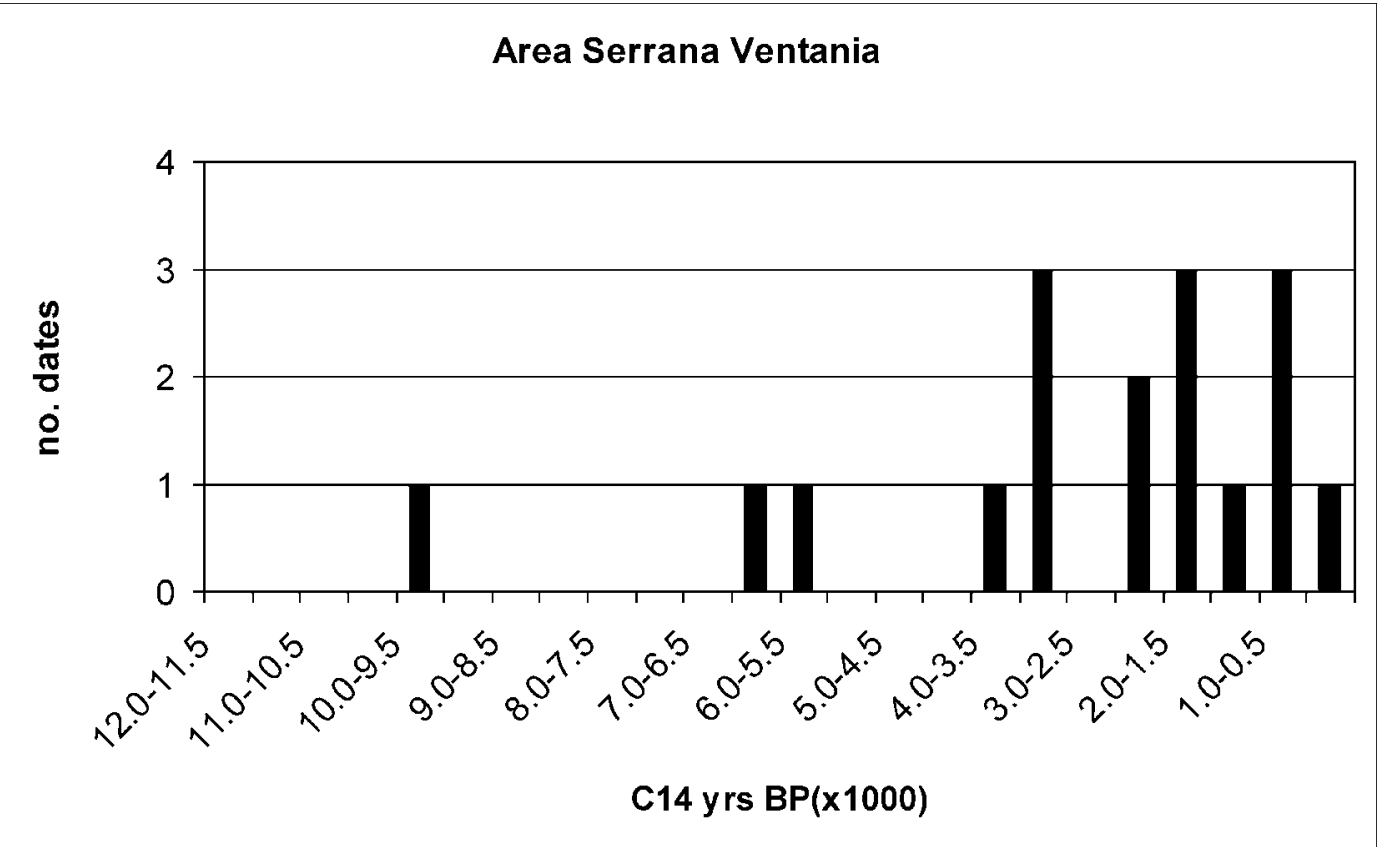

Fig. 18 - Frequency of radiocarbon ages for archaeological sites from Area Serrana de Ventania region, Argentinian Pampas, 500 year intervals (uncalibrated). 


\section{Subregion Pampa Seca}

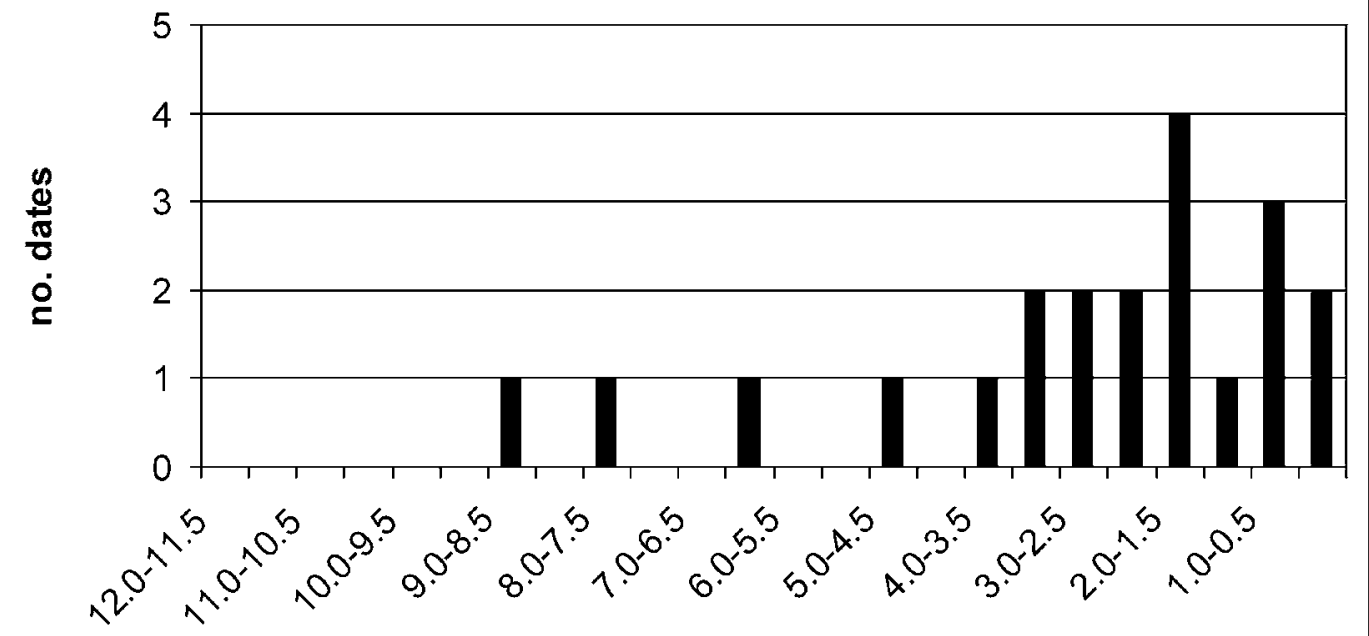

C14 yrs BP(x1000)

Fig. 19 - Frequency of radiocarbon ages for archaeological sites from Pampa Seca region, Argentinian Pampas, 500 year intervals (uncalibrated).

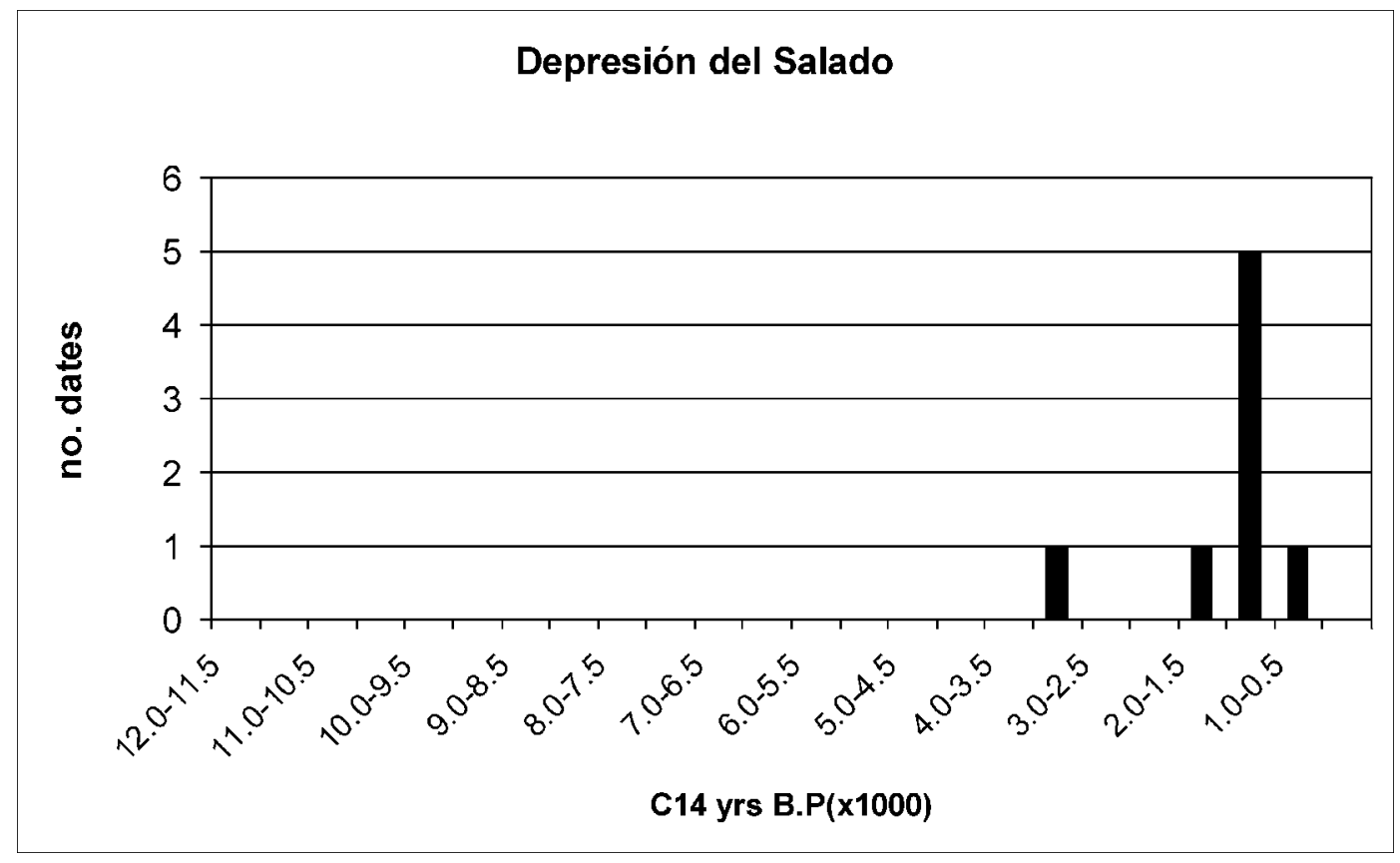

Fig. 20 - Frequency of radiocarbon ages for archaeological sites from Depresión del Salado region, Argentinian Pampas, 500 year intervals (uncalibrated). 


\section{Pampas (Total)}

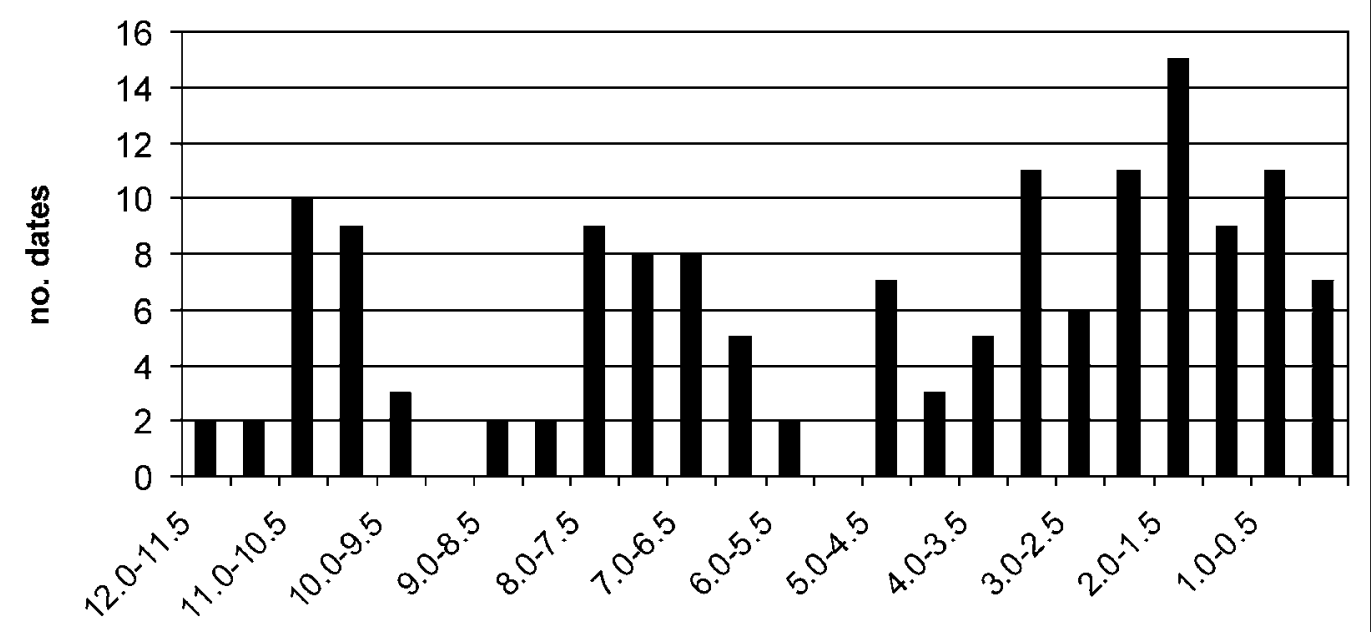

C14 yrs BP(x1000)

Fig. 21 - Total frequency of radiocarbon ages for the Argentinian Pampas, 500 year intervals (uncalibrated).

\section{Pampean Paleosols}

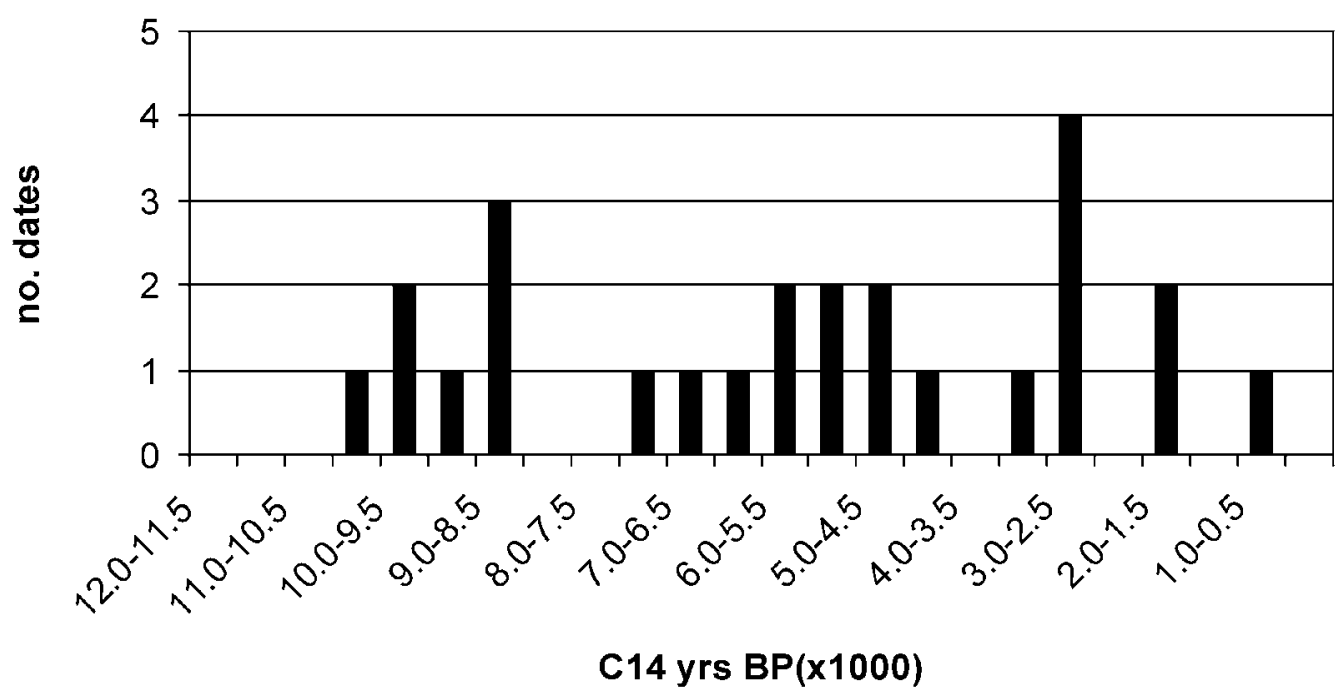

Fig. 22 - Frequency of radiocarbon ages from soil organic matter, Pampean paleosols, 500 year intervals (uncalibrated). 
ARAUJO, A.G.M.; PILÓ, L.B.; NEVES, W.A.; ATUI, J.P.V. Human occupation and paleoenvironments in South America: expanding the notion of an “Archaic Gap”. Rev. do Museu de Arqueologia e Etnologia, São Paulo, 15-16: 3-35, 2005-2006.

paleosols seem to indicate a delay in relation to the archaeological dates, as if the peaks of human occupation happened always before the peaks of soil formation. It is possible that pedogenetic factors are responsible for this rejuvenating effect, a phenomenon already addressed by Pessenda et al. (2001). Comparing dates from soil profiles at eight localities in Brazil, the authors showed that dates obtained from total soil organic matter (SOM) showed significantly younger ages than the humin fraction (considered to be the older organic component of the soil) or than ages obtained from charcoal. Differences in ages between total SOM and humin obtained in the Brazilian samples ranged between $13 \%$ and $209 \%$. In general, charcoal ages were similar and/or older than the humin ages. Therefore, the lag between the paleosol chronology (obtained by total SOM in most cases) and the archaeological chronology (obtained mostly by charcoal) can be easily explained. As we shall see, in Argentina, as well as in Brazil, archaeologists have a strong attachment to the idea of "Climatic Optimum" as a "moist and warm" period, instead of "dry and warm”. This lead some authors to believe that humans abandoned vast portions of the landscape due to "excess of moisture" (e.g., Loponte 1996/98 apud Tonni and Politis 1980; Schmitz et al. 1989).

\section{Conclusions}

The Holocene in South America was marked by dry periods that affected the lives of humans in a intelligible way. Ancient populations had to move across vast spaces in order to avoid the consequences of climatic changes. This pattern has already been observed in the Northern Hemisphere (e.g., Weiss and Bradley 2001) and in the Andean zone (e.g., Nuñez et al. 2002), as well in other parts of the World (Perry and Hsu 2000), where aridity and water availability are obvious constraints to human occupation. In this paper we show that this abandonment pattern is much more ubiquitous, affecting humans in extra-Andean settings such as the Brazilian lowlands and Argentinean Pampas. For a large area in Central Brazil, comprising about $920,000 \mathrm{~km}^{2}$ (slightly larger than the areas of France and Germany together - see Araujo et al. 2005) evidence of major gaps in human occupation is observable both at rock shelters and in the pattern of dates at open-air sites. We believe that more archaeological data would make the picture clearer, but the existing information is already sufficient to show that climate had a strong influence on the observed patterns.

Of course, there are some rockshelters in the interior that constitute exceptions to this picture of Holocene abandonment. Among those in Brazil, we can cite Santa Elina (Vialou et al. 2000) in Mato Grosso State, Gruta do Gavião (Silveira 1994) in Pará State, Toca da Esperança (Martin 1997) in Bahia State, Lapa Vermelha IV (Laming-Emperaire et al. 1975) in Minas Gerais State, and Lapa dos Bichos (Kipnis 2001), also in Minas Gerais. All these sites showed continuous occupation during the mid-Holocene, the causes of which can be numerous. Local, microclimatic conditions could be a possible answer. However, a detailed diachronic analysis of the artifact distributions may also show a decrease in the mid-Holocene occupation in all or some of these sites. These avenues of inquiry are, however, outside the scope of this paper, and the topic deserves much more research.

Our conclusions could be regarded as counterintuitive by some, since many South American archaeologists believe that the "altithermal" (the increase in temperature during the middle Holocene) is synonymous to "Climatic Optimum” (an increase in temperature and moisture). Although widely recognized in Europe (e.g., García et al. 2002; Kalis et al. 2003; Mastronuzzi and Sansó 2002), the period called "Holocene Climatic Optimum" is not a worldwide phenomenon. For instance, Ab’Sáber (1980) suggested that during the middle Holocene some regions in Brazil (mainly intermontane/interplateau depressions) could be subject to dry climates due to the weakening of polar air masses. As the author put (op. cit.:4), an increase in moisture does not follow an increase in temperature.

Finally, we would like to suggest that humans might be regarded as good paleoenvironmental markers for the Holocene, since their presence seems to be clearly associated with a threshold of water availability, either in a direct manner, or following a set of constraints related to the foodstuff they sought. In this light, we propose that archaeological data should be better explored, and regarded as a valuable basis for paleoenvironmental inferences. 
ARAUJO, A.G.M.; PILÓ, L.B.; NEVES, W.A.; ATUI, J.P.V. Human occupation and paleoenvironments in South America: expanding the notion of an “Archaic Gap”. Rev. do Museu de Arqueologia e Etnologia, São Paulo, 15-16: 3-35, 2005-2006.

\section{Acknowledgements}

We would like to thank Marie-Pierre Ledru for important suggestions regarding the content and structure of the paper. Diana Mazzanti, Carlos
Quintana, Eduardo Tonni, Adriana S. Dias, and André Jacobus kindly furnished unpublished data and bibliography. James Welch revised the English version. We remain responsible for any errors or omissions.

ARAUJO, A.GM.; PILÓ, L.B.; NEVES, W.A.;ATUI, J.P.V. Human occupation and paleoenvironments in South America: expanding the notion of an “Archaic Gap”. Rev. do Museu de Arqueologia e Etnologia, São Paulo, 15: 3-35, 2005.

ABSTRACT: An overview of the archaeological data produced in the last decades for Brazil and neighbouring countries, coupled with a background of recent studies on paleoenvironments, suggests that during the mid-Holocene vast areas of South America ceased to be occupied by human groups. Independent data coming from dated human skeletons, rockshelter stratigraphy, and chronology of open-air sites converge to the idea that these areas were, at least, strongly depopulated. Paleoenvironmental data suggest that dryness events constitute the major cause behind the observed trends. Our conclusions expand the already perceived notion that climatic stresses had a major role in the shaping of human settlement patterns in marginal environments, such as deserts and high-altitude settings, showing that the same can occur in tropical and subtropical lowlands.

\section{UNITERMS: Archaeology - Paleoenvironment-Holocene-Brazil-Argentina}

\section{References}

AB'SÁBER, A.N.

1980 Razões da retomada parcial de semi-aridez holocênica, por ocasião do "Otimum Climaticum”. Inter-Facies Escritos e Documentos, 8: 1-13.

ABSY, M.L.; CLEEF, A.M.; FOURNIER, M.; MARTIN, L.; SERVANT, M.; SIFEDDINE, A.; FERREIRA DA SILVA, M.; SOUBIES, F.; SUGUIO, K.; TURCQ, B. ; VAN DER HAMMEN, T.

1991 Mise en évidence de quatre phases d'ouverture de la forêt dense dans le sud-est de l'Amazonie au cours des 60,000 dernières années. Première comparaison avec d'autres régions tropicales. Comptes Rendus d'Academie des Sciences, Paris, Serie II, 312: 673-678.

ALEXANDRE, A.; MEUNIER, J.-D.; MARIOTTI, A.; SOUBIES, F.

1999 Late Holocene phytolith and carbon-isotope record from a latosol at Salitre, south-central Brazil. Quaternary Research, 51:187-194.

ARAUJO, A.G.M.; NEVES,W.A.; PILÓ, L.B.

2003 Eventos de seca no Holoceno e suas implicações no povoamento pré-histórico do
Brasil Central. Paper presented at the IX Congresso da Associação Brasileira de Estudos do Quaternário, Recife.

ARAUJO, A. G. M.; .; NEVES,W.A.; PILÓ, L.B.; ATUI, J.P.V.

2005 Holocene dryness and human occupation in Brazil during the “Archaic Gap”. Quaternary Research, 64:298-307.

ARAUJO, A.G.M.; PILÓ, L.

2005 Processos de Formação em Sítios Abrigados na região de Lagoa Santa, MG: O Papel da Contribuição Antrópica e natural no Aporte de Sedimentos. Paper presented at the XIII Congresso da Sociedade de Arqueologia Brasileira, Campo Grande, MT.

AULER, A.S.; SMART, P.L.

2001 Late Quaternary paleoclimate in semiarid Northeastern Brazil from U-series dating of travertine and water-table speleothems. Quaternary Research, 55: 159-167.

BAKER, P.A.; SELTZER, G.O.; FRITZ, S.C.; DUNBAR, R.B.; GROVE, M.J.; TAPIA, P.M.; CROSS, S.L.; ROWE, H.D.; BRODA, J.P.

2001 The history of South American tropical 
ARAUJO, A.G.M.; PILÓ, L.B.; NEVES, W.A.; ATUI, J.P.V. Human occupation and paleoenvironments in South America: expanding the notion of an “Archaic Gap”. Rev. do Museu de Arqueologia e Etnologia, São Paulo, 15-16: 3-35, 2005-2006.

precipitation for the past 25,000 years. Science, 291: 640-643.

BARBERI, M.; SALGADO-LABORIAU, M.L.; SUGUIO, K.

2000 Paleovegetation and paleoclimate of "Vereda de Águas Emendadas”, central Brazil. Journal of South American Earth Sciences, 13: 241-254.

BARBERI, M.R.

2001 Mudanças Paleoambientais na Região dos Cerrados do Planalto Central Durante o Quaternário Tardio: O Estudo da Lagoa Bonita, DF. Ph.D. Dissertation, Universidade de São Paulo.

BARBOSA, A.I.

1991 Projeto Serra Geral. In Anais do I Simpósio de Pré-História do Nordeste Brasileiro, CLIO Série Aqueológica. vol. 4: 35-38.

BARRIENTOS, G.; PEREZ, S.I.

2005 Was there a population replacement during the Late mid-Holocene in the southeastern Pampas of Argentina? Archaeological evidence and paleoecological basis. Quaternary International, 132:95-105.

BEHLING $\mathrm{H}$.

1995 Investigations into the Late Pleistocene and Holocene history of vegetation and climate in Santa Catarina (S Brazil). Vegetation History and Archaeobotany, 4: 127-152.

1997 Late Quaternary vegetation, climate and fire history of the Araucaria forest and campos region from Serra Campos Gerais, Parana State (South Brazil). Review of Palaeobotany and Palynology, 97:109-121.

1998 Late Quaternary vegetational and climatic changes in Brazil. Review of Palaeobotany and Palynology, 99 (2): 143-156.

2002 South and southeast Brazilian grasslands during Late Quaternary times: a synthesis. Paleogeography, Palaeoclimatology, Palaeoecology, 177: 19-27.

BEHLING, H.; BAUERMANN, S.G.; NEVES, P.C.P.

2001 Holocene environmental changes in the São Francisco de Paula region, southern Brazil. Journal of South American Earth Sciences, 14: 631-639.

BEHLING, H.; BERRIO, J.C.; HOOGHIEMSTRA, H.

1999 Late Quaternary pollen records from the middle Caquetá river basin in central Colombian Amazon. Palaeogeography, Palaeoclimatology, Palaeoecology, 145: 193-213.

BEHLING, H.; HELGE, W.A.; PÄTZOLD, J.; WEFER, G.

2000 Late Quaternary vegetational and climate dynamics in northeastern Brazil, inferences form marine core GeoB 3104-1. Quaternary Science Reviews, 19: 981-994.

BEHLING, H.; HOOGHIEMSTRA, $\mathrm{H}$.

2001 Neotropical savanna environments in space and time: Late Quaternary interhemispheric comparisons. V. Markgraf (Ed.) Interhemispheric Climate Linkages. Academic Press, San Diego: 307-323.
BEHLING H.; NEGRELLE, R.R.B.

2001 Tropical rain forest and climate dynamics of the Atlantic Lowland, Southern Brazil, during the Late Quaternary. Quaternary Research, 56: 383-389.

BEHLING H.; PILLAR, V.D.; BAUERMANN, S.G.

2005 Late Quaternary grassland (Campos), gallery forest, fire and climate dynamics, studied by pollen, charcoal and multivariate analysis of the São Francisco de Assis core in western Rio Grande do Sul (southern Brazil). Review of Palaeobotany and Palynology, 133: 235-248.

BEHLING H.; PILLAR, V.D.; ORLÓCI, L.; BAUERMANN, S.G

2004 Late Quaternary Araucaria forest, grassland (Campos), fire and climate dynamics, studied by high-resolution pollen, charcoal and multivariate analysis of the Cambará do Sul core in southern Brazil. Palaeogeography, Palaeoclimatology, Palaeoecology, 203:277-297.

BELTRÃO, M.C.M.; ENRIQUEZ, C.R.; DANON, J.; ZULETA, E.; POUPEAU, G.

1986 Thermoluminescence dating of burned cherts from Alice Böer Site (Brazil). A.L. Bryan (Ed.) New Evidence for the Pleistocene Peopling of the Americas. University of Maine, Orono: 203-219.

BETANCOURT, J.L.; LATORRE, C.; RECH, J.A.; QUADE, J.; RYLANDER, K.A.

2000 A 22,000-year record of monsoonal precipitation from northern Chile's Atacama Desert. Science, 289: 1542-1546.

BIRD, R. M.; DIAS JR., O.; CARVALHO, E.T.

1991 Subsídios para a arqueobotânica no Brasil: o milho antigo em cavernas de Minas Gerais. Revista de Arqueologia, 6:14-31.

BRADBURY, J.P.; GROSJEAN, M.; STINE, S.; SYLVESTRE, F.

2001 Full and Late Glacial lake records along the PEP 1 Transect: their role in developing interhemispheric paleoclimate interactions. V. Markgraf (Ed.) Interhemispheric Climate Linkages. San Diego, Academic Press: 265-291.

BRYAN, A.; GRUHN, R.

1978 Results of a test excavation at Lapa Pequena, MG, Brazil. Arquivos do Museu de História Natural da UFMG, III: 261-325.

1993 Archaeological research at six cave or rockshelter sites in interior Bahia, Brazil. Brazilian Studies. Center for the Study of the First Americans, Corvallis, Oregon.

BUENO, L.M.R.

2005 Variabilidade Tecnológica nos Sítios Líticos da Região do Lajeado, Médio Rio Tocantins. PhD, Universidade de São Paulo.

Carneiro Filho, A.; Schwartz D.; Tatumi, S.; Rosique, T.

2002 Amazonian paleodunes provide evidence for drier climate phases during the Late PleistoceneHolocene. Quaternary Research, 58:205-209.

CHAUSSON, Y.; DÉLIBRIAS, G

1993 Datações realizadas no sítio de Santana do 
ARAUJO, A.G.M.; PILÓ, L.B.; NEVES, W.A.; ATUI, J.P.V. Human occupation and paleoenvironments in South America: expanding the notion of an “Archaic Gap”. Rev. do Museu de Arqueologia e Etnologia, São Paulo, 15-16: 3-35, 2005-2006.

\section{Riacho. Arquivos do Museu de História Natural da UFMG, XIII/XIV: 395-400. \\ CHAVES, S.A.M. \\ 2000 Estudo palinológico de coprólitos pré-} históricos holocenos coletados na Toca do Boqueirão do Sítio da Pedra Furada Contribuições paleoetnológicas, paleoclimáticas paleoambientais para a região sudeste do Piauí - Brasil. Revista do Museu de Arqueologia e Etnologia, 10, São Paulo: 103-120.

CHMYZ, I.C.

1983 Projeto Arqueológico Itaipu - Sétimo

Relatório das Pesquisas Realizadas na Área de Itaipu (1981/83). Convênio Itipu/IPHAN.

COLINVAUX, P.A.; DE OLIVEIRA, P.E.; MORENO, J.E.; BUSH, M.B.

1996 A long pollen record from lowland Amazonia: Forest and cooling in glacial times. Science, 274 (5284): 85-88.

COLLET, G

1985 Novas informações sobre os sambaquis fluviais do Estado de São Paulo. Arquivos do Museu de História Natural da UFMG, X: 311-324.

DE BLASIS, P.A.

2001 Os mais antigos soberanos da costa. Paper presented at the Resumos do XI Congresso da Sociedade de Arqueologia Brasileira, Rio de Janeiro.

DE OLIVEIRA, P.E.

1992 A Palynological Record of Late Quaternary Vegetational and Climatic Change in Southeastern Brazil. Ph.D. Dissertation, Ohio State University.

DE OLIVEIRA, P.E.; BARRETO, A.M.; SUGUIO, K.

1999 Late Pleistocene/Holocene climatic and vegetational history of the Brazilian caatinga: the fossil dunes of the middle São Francisco River. Palaeogeography, Palaeoclimatology, Palaeoecology, 152: 319-337.

DIAS, A.S.; JACOBUS, A.L.

2000 Quão antigo é o povoamento do sul do Brasil? Workshop Internacional do INQUA A Colonização da América do Sul na Transição Pleistoceno/Holoceno. Páginas?

2001 The antiquity of the peopling of southern Brazil. Current Research in the Pleistocene, 18: 17-19.

DIAS JR., O.F.

1991 Desenvolvimento cultural no horizonte 9.000/ 4.000 anos A.P. no Brasil Tropical. Revista de Arqueologia Americana, 4: 55-87.

ENFIELD, D.B.; MESTAS-NUÑEZ, A.M.

2001 Interannual to multidecadal climate variability and its relationship to global sea surface temperatures. V. Markgraf (Ed.) Interhemispheric Climate Linkages. San Diego, Academic Press: 17-29.

FERRAZ-VICENTINI, K.R.; SALGADO-LABORIAU, M.L

1996 Palynological analysis of a palm swamp in Central Brazil. Journal of South American Earth Sciences, 9: 207-219.
FLEGENHEIMER, N.; ZÁRATE, $M$.

1997 Considerations on radiocarbon and calibrated dates from Cerro La China and Cerro El Sombrero, Argentina. Current Research in the Pleistocene, 14: 27-28.

FOGAÇA, E.

2001 Mãos para o Pensamento- A Variabilidade Tecnológica de Indústrias Líticas de Caçadores-Coletores Holocênicos a partir de um Estudo de Caso: as Camadas VIII e VII da Lapa do Boquete (Minas Gerais, Brasil 12.000/ 10.500 B.P.). Ph.D. Dissertation, Universidade Federal do Rio Grande do Sul.

FREITAS, H.A.; PESSENDA, L.C.;ARAVENA, R.; GOUVEIA, S.E.; RIBEIRO, A.S.; BOULET, R.

2001 Late Quaternary vegetation dynamics in the Southern Amazon basin inferred from carbon isotopes in soil organic matter. Quaternary Research, 55: 39-46.

FRITZ, S.C.; METCALFE, S.E.; DEAN, W.

2001 Holocene climate patterns inthe Americas inferred from paleolimnological records. V. Markgraf (Ed.) Interhemispheric Climate Linkages. San Diego, Academic Press: 241-263.

GARCÍA, A.

2005 Human occupation of the Central Andes of Argentina (32-34S) during the mid-Holocene. Quaternary International, 132: 61-70.

GARCÍA, A.; ZÁRATE, M.; PAEZ, M.M.

1999 The Pleistocene/Holocene transition and human occupation in the Central Andes of Argentina: Agua de la Cueva locality. Quaternary International, 53/54: 43-52.

GARCÍA, M.J.G.; VALIÑO, M.D.; RODRÝGUEZ, A.V.; ZAPATA, M.B.

2002 Late-glacial and Holocene palaeoclimatic record from Sierra de Cebollera (northern Iberian Range, Spain). Quaternary International, 93/94: 13-18.

GARREAUD, R.D.

2000 Cold air incursions over subtropical and tropical South America: Mean structure and dynamics. Monthly Weather Review, 128: 2544-2559.

GEYH, M.A.; GROSJEAN, M.; NUÑEZ, L.; SCHOTTERER, U.

1999 Radiocarbon reservoir effect and the timing of the Late-Glacial / Early Holocene humid phase in the Atcama Desert (Northern Chile). Quaternary Research, 52: 142-153.

GIL, A.; ZÁRATE, M.; NEME, G.

2005 Mid-Holocene paleoenvironmentsand the archeological record of southern Mendoza, Argentina. Quaternary International, 132: 81-94.

GOUVEIA, S.E.M.; PESSENDA, L.C.; ARAVENA, R.; BOULET, R.; SCHEEL-YBERT, R.; BENDASSOLI, J.A.; RIBEIRO, A.S.F.; FREITAS, H.A.

2002 Carbon isotopes in charcoal and soils in studies of paleovegetation and climate changes during the late Pleistocene and the 
ARAUJO, A.G.M.; PILÓ, L.B.; NEVES, W.A.; ATUI, J.P.V. Human occupation and paleoenvironments in South America: expanding the notion of an “Archaic Gap”. Rev. do Museu de Arqueologia e Etnologia, São Paulo, 15-16: 3-35, 2005-2006.

Holocene in the southeast and centerwest regions of Brazil. Global and Planetary Change, 33: 95-106.

GRIMM, E. C.; LOZANO-GARCIA, S.; BEHLING, H.; MARKGRAF, V.

2001 Holocene vegetation and climate variability in the Americas. V. Markgraf (Ed.) Interhemispheric Climate Linkages. San Diego, Academic Press: 325-370.

GROSJEAN, M.; NUÑEZ, L.A.; CARTAJENA, I.; MESSERLI, B

1997 Mid-Holocene climate and culture change in the Atacama desert, northern Chile. Quaternary Research, 48: 239-246.

GROSJEAN, M.; VAN LEEUWEN, J.F.N.; VAN DER KNAAP, W.O.; GEYH, M.A.;AMMANN, B.; TANNER, W.; MESSERLI,

B.; NUÑEZ, L.A.; VALERO-GARCÉS, B.L.; VEIT, H.

2001 A 22,000 C14 year BP sediment and pollen record of climate change from Laguna Miscanti $\left(23^{\circ} \mathrm{S}\right)$, northern Chile. Global and Planetary Change, 28: 35-51.

HABERLE, S.G.; LEDRU, M.-P.

2001 Correlations among charcoal records of fires form the past 16,000 years in Indonesia, Papua New Guinea, and Central and South America. Quaternary Research, 55: 97-104.

HURT, W.R.; BLASI, O.

1969 O Projeto Arqueológico "Lagoa Santa” Minas Gerais, Brasil. Arquivos do Museu Paranaense - Nova Série, Arqueologia, 4: 1-60.

IRIONDO, $\mathrm{M}$.

1997 Comment on A. Prieto’s (1996) paper “Late Quaternay vegetational and climatic changes in the Pampa grassland of Argentina”. Quaternary Research, 48: 251-252.

1999 Last glacial maximum and hypsithermal in the Southern Hemisphere. Quaternary International, 62: 11-19.

JENNY,B.; VALERO-GARCÉS, B.L.; VILLA-MARTÍNEZ, R.; URRUTIA, R.; GEYH, M.; VEIT, H.

2002 Early to Mid-Holocene aridity in central Chile and southern westerlies: the Laguna Aculeo record (34 S). Quaternary Research, 58:160-170.

KALIS, A.J.; MERKT, J.; WUNDERLICK, J.

2003 Environmental changes during the Holocene climatic optimum in central Europe - human impact and natural causes. Quaternary Science Reviews, 22: 33-79.

KIPNIS, R.

2002 Foraging Societies of Eastern Central Brazil: An Evolutionary Ecological Study of Subsistence Strategies During the Terminal Pleistocene and Early/Middle Holocene. Ph.D. Dissertation, University of Michigan.

KRÖHLING, D.M

1999 Upper Quaternary geology of the lower Carcarañá basin, North Pampa, Argentina. Quaternary International, 57/58: 135-148.
KRÖHLING D.M.; IRIONDO, M.

1999 Upper Quaternary palaeoclimates of the Mar Chiquita area, North Pampa, Argentina. Quaternary International, 57/58: 149-163.

LAMING-EMPERAIRE, A.; PROUS, A.; VILHENA DE

MORAES, A.; BELTRÃO, M.C. (EDS.)

1975 Grottes et Abris de la Region de Lagoa Santa, Minas Gerais, Bresil - Premier Rapport de la Mission Archéologique Franco-Brésilienne de Lagoa Santa. 1.

LEDRU, M.-P.

1993 Late Quaternary environmental and climatic changes in Central Brazil. Quaternary Research, 39: 90-98.

LEDRU, M.-P.; BRAGA, P.I.S.; SOUBIES, F.; FOURNIER, M.; MARTIN, L.; SUGUIO, K.; TURCQ, B.

1996 The last 50,000 years in the Neotropics (Southern Brazil): Evolution of vegetation and climate. Palaeogeography, Palaeoclimatology, Palaeoecology, 123: 239-257.

LEDRU, M.-P.; MOURGUIART, P.

2001 Late glacial vegetation records in the Americas and climatic implications. V. Markgraf (Ed.) Interhemispheric Climate Linkages. San Diego, Academic Press: 371-390.

LEDRU, M.-P.; MOURGUIART, P.; CECCANTINI, G.; TURCQ, B.; SIFEDDINE, A.

2002 Tropical climates in the game of two hemispheres revealed by abrupt climatic change. Geeology, 30 (3):275-278.

LEDRU, M.-P.; SALGADO-LABORIAU, M. L.; LORSCHEITER, M. L.

1998 Vegetation dynamics in southern and central Brazil during the last 10,000 yr B.P. Review of Palaeobotany and Palynology, 99: 131-142.

LIMA, A.P.S.

2005 Análise dos Processos Formativos do Sítio Capelinha: Estabelecimento de um Contexto Microrregional. MA, Universidade de São Paulo.

LIMA, J.M.D.

1985 Arqueologia da Furna do Estrago, Brejo da Madre de Deus - PE. CLIO - Série Arqueológica, 7: 97-111.

LIMA, J.M.D.

1991 Dois períodos de subsistência no agreste pernambucano: 9.000 e 2.000 AP. Anais do I Simpósio de Pré-História do Nordeste - CLIO Série Arqueológica, 4: 57-61.

MACHADO, L.C.

1990 Sobre as práticas funerárias de cremação e suas variações em grutas do norte e noroeste de Mians Gerais. Revista do CEPA - Santa Cruz do Sul, 17 (20): 235-247.

MARENGO, J.A.; ROGERS, J.C.

2001 Polar air outbreaks in the Americas: assessment and impacts during modern and past climates. In Interhemispheric Climate Linkages. V. Markgraf (Ed.) Interhemispheric Climate Linkages. San Diego, Academic Press: 31-51. 
ARAUJO, A.G.M.; PILÓ, L.B.; NEVES, W.A.; ATUI, J.P.V. Human occupation and paleoenvironments in South America: expanding the notion of an “Archaic Gap”. Rev. do Museu de Arqueologia e Etnologia, São Paulo, 15-16: 3-35, 2005-2006.

MARKGRAF, V.; BAUMGARTNER, T.R.; BRADBURY, J.P.; DIAZ, H.F.; DUNBAR, R.B.; LUCKMAN, B.H.; SELTZER, G.O.; SWETNAM, T.W.; VILLALBA, R.

2000 Paleoclimate reconstruction along the PoleEquator-Pole transect of the Americas (PEP 1). Quaternary Science Reviews, 19: 125-140.

MARTIN, G.

1997 Pré-História do Nordeste do Brasil. 2nd ed. Recife: Editora Universitária da Universidade Federal de Pernambuco.

MARTINA, L.; BERTAUX, J.; CORRÉGE, T.; LEDRUB. M.P.; MOURGUIARTC, P.; SIFEDDINED, A.; SOUBIÈSD, F.; WIRRMANND, D.; SUGUIOE, K.; TURCQ, B.

1997 Astronomical forcing of contrasting rainfall changes in tropical South America between 12,400 and $8800 \mathrm{cal}$ yr B.P. Quaternary Research, 47: 117-122.

MARTIN, L.; FOURNIER, M.; SIFEDDINE, A.; TURCQ, B.; ABSY, M.L.; FLEXOR, J. M.

1993 Southern Oscillation signal in South American paleoclimatic data of the last 7000 years. Quaternary Research, 39: 338-346.

MASTRONUZZI, G.; SANSÓ, P.

2002 Holocene coastal dune development and environmental changes in Apulia (southern

MAZZANTI, D.L. Italy). Sedimentary Geology, 150: 139-152.

1996 An archaeological sequence of huntergatherers in the Tandilia range: Cueva Tixi, Buenos Aires, Argentina. Antiquity, 70: 450-452.

1997 Excavaciones arqueológicas en el sitio Cueva Tixi, Buenos Aires, Argentina. Latin American Antiquity, 8 (1): 55-62.

2002 Secuencia arqueologica del Sitio 2 de la localidad arqueologica Amalia (Provincia de Buenos Aires). D. Mazzanti; M. Berón; F. Oliva Del Mar a los Salitrales (Eds.) Dies Mil Años de Historia Pampeana en el Umbral del Tercer Milenio. Mar del Plata, LARBO/SAA : 327-339.

2004 Human settlements in caves and rock shelters during the Pleistocene - Holocene in the Eastern of Tandilia Range, Pampean Region, Argentina. L. Miotti, M. Salemme; N. Flegenheimer (Eds.) Where the South Winds Blow: Ancient Evidences for Paleo South Americans. Center for the Study of First Americans, Texas: 135-167.

MELO, M.S.; COIMBRA, A.M.; CUCHIERATO, G.

2001 Genesis of Quaternary colluvial-eluvial sedimentary covers in southeastern Brazil. Quaternaire, 12 (3):179-188.

MILLER,E.T.

1987 Pesquisas arqueológicas paleoindígenas no Brasil Ocidental. Estudios Atacameños, 8: 37-61.

MOY, C.M.; SELTZER, G.O.; RODBELL, D.T.; ANDERSON, D.M.

2002 Variability of El Niño/Southern Oscillation activity at millenial timescales during the Holocene epoch. Nature, 420: 162-165.
NIMER, E.

1989 Climatologia do Brasil. 2nd ed. Rio de Janeiro: IBGE.

NOELLI, F.S

2000 A ocupação humana na Região Sul do Brasil: arqueologia, debates e perspectivas - 18722000. Revista USP - Dossiê Antes de Cabral, 44: 218-269.

NUÑEZ, L.; GROSJEAN, M.; CARTAJENA, I.

1999 Un ecorefugio oportunístico en la puna de Atacama. Estudios Atacameños, 17: 125-174.

NUÑEZ, L.; GROSJEAN, M.; CARTAJENA, I.

2001 Human dimensions of Late Pleistocene/ Holocene arid events in southern South America. V. Markgraf (Ed.) Interhemispheric Climate Linkages. San Diego, Academic Press: 105-117.

2002 Human occupations and climate change in the Puna de Atacama, Chile. Science, 298: 821-824.

NUÑEZ, L.; SANTORO, C.M.

1988 Cazadores de la puna seca y salada del área centro-sur Andina (Norte de Chile). Estudios Atacameños, 9: 11-60.

PARELLADA, C.I.

2006 Estudo Arqueológico no Alto Vale do Rio Ribeira: Área do Gasoduto Bolívia-Brasil, Trecho X, Paraná. PhD Dissertation, Universidade de São Paulo.

PARENTI, F.

2001 Le Gisement Quaternaire de Pedra Furada (Piauí, Brésil) - Stratigraphie, Chronologie, Évolution Culturelle. Ministére des Affaires Étrangères.

PARIZZI, M.G.

1993 A Gênese e a Dinâmica da Lagoa Santa com Base em Estudos Palinológicos, Geomorfológicos e Geológicos de sua Bacia. M.A. Dissertation, Universidade Federal de Minas Gerais.

PERRY, C.A.; HSU, K.J.

2000 Geophysical, archaeological, and historical evidence support a solar-output model for climate change. Proceedings of the National Academy of Sciences, 97 (23): 12433-12438.

PESSENDA, L.C.R.; GOUVEIA, S.E.M.; ARAVENA, R.

2001 Radiocarbon dating of total soil organic matter and humin fraction and its comparison with C14 ages of fossil charcoal. Radiocarbon, 43 (2B): 595-601.

POLITIS, G; MADRID, P.E.E.

2001 Arqueologia Pampeana: Estado actual y perspectivas. E.E. Berberián; A.E. Nielsen (Eds.) Historia Argentina Prehispanica, vol. II. Buenos Aires, Editorial Brujas: 737-814.

PRIETO,A.R.

1996 Late Quaternary vegetational and climatic changes in the Pampa grassland of Argentina. Quaternary Research, 45: 73-88.

1997 Reply to the Letter to the Editor on "Late Quaternary vegetational and climatic changes 
ARAUJO, A.G.M.; PILÓ, L.B.; NEVES, W.A.; ATUI, J.P.V. Human occupation and paleoenvironments in South America: expanding the notion of an “Archaic Gap”. Rev. do Museu de Arqueologia e Etnologia, São Paulo, 15-16: 3-35, 2005-2006.

in the Pampa grassland of Argentina” by M. Iriondo. Quaternary Research, 48: 253-256.

PROUS, A.

1991 Santana do Riacho - Tomo I. A. Prous (Ed.) Arquivos do Museu de História Natural da UFMG, vol. XII. Belo Horizonte, 384 pp.

1997 Archéologie du cours moyen du Rio São Francisco (vallées des rios Peruaçu et Cochá). A. Prous; L. Ribeiro (Eds.) Arquivos do Museu de História Natural da UFMG, XVII/ XVIII, Belo Horizonte: 19-67.

PROUS, A.; COSTA, F.; ALONSO, M.

1997 Arqueologia da Lapa do Dragão. Arquivos do Museu de História Natural da UFMG, XVII/ XVIII: 139-209.

PROUS, A.; FOGAÇA, E.

1999 Archaeology of the Pleistocene-Holocene boundary in Brazil. Quaternary International, 53/54: 21-41.

RICK, J.W.

1987 Dates as data: an examination of the Peruvian preceramic radiocarbon record. American Antiquity, 52 (1): 55-73.

RODRIGUES-FILHO, S.; BEHLING H.; IRION, G; MÜLLER, G

2002 Evidence for lake formation as a response to an inferred Holocene climatic transition in Brazil. Quaternary Research, 57: 131-137.

SALGADO-LABORIAU, M.L.; CASSETI, V.; FERRAZVICENTINI, K.R.; MARTIN, L.; SOUBIES, F.; SUGUIO, K.; TURCQ, B.

1997 Late Quaternary vegetational and climatic changes in cerrado and palm swamp from central Brazil. Palaeogeography, Palaeoclimatology, Palaeoecology, 128: 215-226.

SALGADO-LABOURIAU, M.L.

1997 Late Quaternary palaeoclimate in the savannas of South America. Journal of Quaternary Science, 12: 371-379.

SALGADO-LABOURIAU, M.L.; BARBERI, M.; FERRAZ VICENTINI, K.R.; PARIZZI, M.G.

1998 A dry climatic event during the late Quaternary of tropical Brazil. Review of Paleobotany and Palinology, 99 (2):115-129.

SCHMITZ, P.I.

1980 O Paleo-Índio em Goiás, Temas de Arqueologia Brasileira. Instituto Goiano de Pré-História e Antropologia da Universidade Católica de Goiás, Goiânia: 22-33.

SCHMITZ, P.I.; BARBOSA, A.S.; JACOBUS, A.; RIBEIRO, M.B.(EDS.)

1989 Arqueologia nos Cerrados do Brasil Central, 44. Instituto Anchietano de Pesquisas, São Leopoldo.

SCHMITZ, P.I.; BARBOSA, A.S.; MIRANDA, A.F.; RIBEIRO, M.B.; BARBOSA, M.O.(EDS.)

1996 Arqueologia nos Cerrados do Brasil Central, Sudoeste da Bahia e Leste de Goiás - O Projeto Serra Geral, 52. Instituto Anchietano de Pesquisas, São Leopoldo.
SERVANT, M.; MALEY, J.;TURCQ, B.; ABSY, M.; BRENAC, P.; FOURNIER, M.; LEDRU, M.-P.

1993 Tropical forest changes during the Late Quaternary in African and South American lowlands. Global and Planetary Changes, 7: 25-40.

SIFEDDINE, A.; ALBUQUERQUE, A.S.; LEDRU, M.-P.; TURCQ, B.; KNOPPERS, B.; MARTIN, L.; MELLO, L.Z.; PASSENAU, H.; DOMINGUEZ, J.L.; CORDEIRO, R.C.; ABRÃO, J.J.; BITTENCOURT, A.P.

2003 A $21000 \mathrm{cal}$ years paleoclimatic record from Caçó Lake, northern Brazil: evidence from sedimentary and pollen analysis. Palaeogeography, Palaeoclimatology, Palaeoecology, 189: 25-34.

SILVEIRA, M.I.

1994 Estudo Sobre Estratégias de Subsistência de Caçadores-Coletores Pré-Históricos do Sítio Gruta do Gavião, Carajás (Pará). Master’s Thesis, Universidade de São Paulo.

STEVAUX, J.C

2000 Climatic events during the Late Pleistocene and Holocene in the Upper Parana River: correlation with NE Argentina and South-Central Brazil. Quaternary International, 72: 73-85.

SYLVESTRE, F.; SERVANT, M.; SERVANT-VILDARY, S.; CAUSSE, C.; FOURNIER, M.; YBERT, J.-P.

1999 Lake-level chronology on the southern Bolivian Altiplano (18 S-23 S) during lateglacial time and the early Holocene. Quaternary Research, 51: 54-66.

TONNI, E.; POLITIS, G.

1980 La distribuición del guanaco (Mammalia, Camelidae) en la Pcia. de Buenos Aires durante el Pleistoceno Tardio y Holoceno. Los factores climáticos como causas de su retracción. Ameghiniana, 17: 53-66.

TONNI, E.P.; CIONE, A.L.; FIGINI, A.J.

1999 Predominance of arid climates indicated by mammals in the pampas of Argentina during the late Pleistocene and Holocene. Palaeogeography, Palaeoclimatology, Palaeoecology, 147: 257-281.

TONNI, E.P.; CIONE, A.L.; FIGINI, A.

2001 Chronology of Holocene pedogenetic events in the Pampean area of Argentina. Current Research in the Pleistocene, 18: 124-127.

TURCQ, B.; ALBUQUERQUE, A.L.S.; CORDEIRO, R.C.; SIFEDDINE, A.; FILHO, F.F.L.S.; SOUZA, A.G.; ABRÃO, J.J.; OLIVEIRA, F B.L.; SILVA, A.O.; CAPITÂNEO, J.

2002 Accumulation of organic carbon in five Brazilian lakes during the Holocene. Sedimentary Geology, 148: 319-342.

TURCQ, B.; PRESSINOTTI, M.M.N. ; MARTIN, L.

1997 Paleohydrology and paleoclimate of the past 33,000 years a the Tamanduá river, Central Brazil. Quaternary Research, 47: 284-294.

URREGO,L.E.

1997 Los bosques inundables del medio Caquetá: caracterización y sucesión. Estudios en la 
ARAUJO, A.G.M.; PILÓ, L.B.; NEVES, W.A.; ATUI, J.P.V. Human occupation and paleoenvironments in South America: expanding the notion of an “Archaic Gap”. Rev. do Museu de Arqueologia e Etnologia, São Paulo, 15-16: 3-35, 2005-2006.

Amazonia Colombiana, vol. XIV, Bogotá, 335pp.

VERNET, J.-L.;WENGLER, L.; SOLARI, M.-E.; CECCANTINI, G.; FOURNIER, M.; LEDRU, M.-P. ; SOUBIES, F.

1994 Feux, climats et végetations au Brésil Central durant l'Holocene: Les données d’un profil de sol à charbons de bois (Salitre, Minas Gerais). Comptes Rendus de l'Academie des Sciences de Paris, 319 (II): 1391-1397.

VIALOU, D.; VILHENA-VIALOU, A.; FIGUTI, L.; BENABDELHADI, B. ; WESOLOWSKI, V.

2000 Relatório do Projeto ' $L$ 'Homme Fossile et ses Paleoenvironnements dans le Bassin du Paraná- Brésil”. Ministére des Affaires Ètrangiéres.

Recebido para publicação em 19 de outubro de 2005.

\section{VILHENA-VIALOU,A.}

1984 Brito: o mais antigo sítio arqueológico do Paranapanema, Estado de São Paulo. Revista do Museu Paulista, Nova Série, XXIX: 9-21.

WALTER, H.V.

1948 A Pré-História da Região de Lagoa Santa (Minas Gerais). Belo Horizonte: Velloso \& Cia. Ltda.

WALTER, H.V.

1958 Arqueologia da Região de Lagoa Santa. Rio de Janeiro: Sedegra Gráfica Ltda.

WEISS, H. ; BRADLEY, R.S.

2001 What drives societal collapse? Science, 291: 609-610. 